\title{
2022 Florida Blueberry Integrated Pest Management Guide ${ }^{1}$
}

\author{
Philip F. Harmon, Oscar E. Liburd, Peter Dittmar, Jeffrey G. Williamson, and Doug Phillips ${ }^{2}$
}

This publication is intended to be a resource for Florida blueberry growers to use in scouting for disease and insect/ mite pest damage; managing disease, insect/mite pests, and weeds; and application of certain plant growth regulators. It is intended for use only as a guide. Specific rates and application methods are on the pesticide label, and these are subject to change at any time. Always refer to and read the pesticide label before making any application. The pesticide label supersedes any information contained in this guide, and it is the legal document referenced for application standards.

\section{Florida Blueberry Disease and Insect Pests by Stage of Plant Development}

\section{Dormant Plants}

\section{PHYTOPHTHORA ROOT ROT}

Phytophthora root rot (PRR) is considered the most serious soilborne disease that affects southern highbush blueberries (SHB). Some SHB cultivars are considered tolerant and others highly susceptible, while rabbiteye cultivars are less affected by the disease. PRR is caused by the oomycete pathogen Phytophthora cinnamomi. Common aboveground symptoms associated with Phytophthora infections are reductions in plant vigor and premature fall discoloration.
Symptoms at ground level and belowground include crown and root rots. Disease on susceptible hosts occurs when certain environmental conditions (primarily a saturated root zone and root wounding) trigger Phytophthora reproduction, infection and symptom development. PRR is typically more severe in low and poorly drained areas of a farm. The pathogen causes root discoloration (dark brown to black, instead of the normal cinnamon brown) and decay. Advanced stages of infection cause plant stunting, wilting, an abnormal or reduced root system, root rot, and plant dieback. Leaf discoloration also typically occurs, including yellowing, reddening with or without marginal burn, abnormal growth of new leaves, and defoliation. Plants affected by PRR may also be more susceptible to other dieback diseases including stem blight. Fungicides with the active ingredient mefenoxam, such as Ridomil Gold SL, are recommended where PRR occurs and are applied twice yearly (typically in January and June) through drip irrigation or as a band application directly to the bed. In addition to the phenylamide fungicide mefenoxam, which is applied to the soil, Aliette (Fosetyl-Al 80\%) and numerous phosphorous acid products, referred to as "phites" or phosphonates, provide some control when applied as summer foliar sprays. See Table 1.

1. This document is HS1156, one of a series of the Horticultural Sciences Department, UF/IFAS Extension. Original publication date March 2009. Revised March 2013, March 2016, September 2018, and November 2021. Visit the EDIS website at https://edis.ifas.ufl.edu for the currently supported version of this publication.

2. Philip F. Harmon, associate professor, Plant Pathology Department; Oscar E. Liburd, professor, Entomology and Nematology Department; Peter Dittmar, assistant professor, Horticultural Sciences Department; Jeffrey G. Williamson, professor, Horticultural Sciences Department; and Doug Phillips, blueberry Extension coordinator, Horticultural Sciences Department, UF/IFAS Gulf Coast Research and Education Center, Wimauma, FL; UF/IFAS Extension, Gainesville, FL 32611.

The Institute of Food and Agricultural Sciences (IFAS) is an Equal Opportunity Institution authorized to provide research, educational information and other services

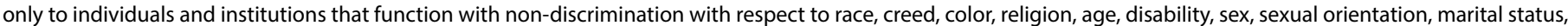

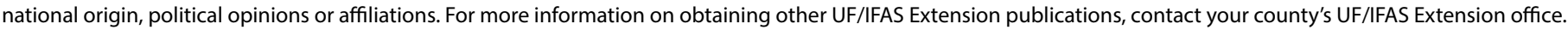
U.S. Department of Agriculture, UF/IFAS Extension Service, University of Florida, IFAS, Florida A \& M University Cooperative Extension Program, and Boards of County Commissioners Cooperating. Nick T. Place, dean for UF/IFAS Extension. 


\section{BLUEBERRY GALL MIDGE}

The blueberry gall midge (BGM) is a tiny fly whose larvae feed on vegetative and floral buds. Typically, gall midge will attack young developing floral and leaf buds, which will cause floral buds to abort or fall off the bush, resulting in poor flowering and "fruit set." With heavy gall midge injury to floral buds, there would be a lighter bloom. Instead of the usual 5 to 6 buds producing several flowers, only 2 may reach maturity, resulting in poor fruit clusters. Blueberry gall midge will also feed on leaf or vegetative buds, leaving young leaves deformed and misshaped. Gall midges lay eggs on warm winter days and at any time during the growing season when the plants are making new flushes of growth. Delegate $^{\circledast}$ (Spinetoram), Exirel ${ }^{\circledast}$ (Cyantraniliprole), diazinon (if labeled for use on your site), Apta (Tolfenpyrad), and Movento ${ }^{\oplus}$ (Spirotetramat) can be applied for gall midge control between flower bud stages 2 and 3 (Figures 2 and 3). Application should take place when the most mature buds first show slight scale separation. Sprays may need to be repeated during warm spells. Bud scale separation may occur as early as December 15th in north Florida. Among rabbiteye cultivars, 'Premier' is often particularly attractive to the gall midge and is a good sentinel variety to monitor. Gall midge sprays can also suppress a prebloom thrips population. See Table 2 and EDIS publication ENY-997, "Blueberry Gall Midge on Southern Highbush Blueberry in Florida” (https://edis.ifas.ufl.edu/publication/IN1239).

\section{IMPORTED FIRE ANTS}

Ant baits employed in early spring as a broadcast treatment usually eliminate most but not all fire ant mounds within treated areas. Under high ant pressure, treating a second time in the fall provides better fire ant control. Most ant baits are slow acting and require up to 8 weeks to control active mounds because they interfere with reproduction, causing a gradual colony die-off. Extinguish ${ }^{\oplus}$ Professional Fire Ant Bait (0.5\% methoprene) is labeled for use on all crop land sites. It is effective but somewhat slower acting than Esteem ${ }^{\odot}$ Ant Bait (0.5\% pyriproxyfen). In order for the bait to be effective, active ant foraging is essential. Worker ants must be attracted to baits so that they will carry the baits back to their colonies. Ideally, temperatures should be warm and sunny. Ant baits work best when the soil is moist but not wet. Avoid applying ant baits when conditions are expected to be cold, overcast, rainy, or very hot. Individual mound treatments are most effective when used as needed for the occasional colony that survives broadcast treatments. Mound treatments using insecticide baits should be applied in a circle 3-4 feet from the mound. Baits should not be placed directly on top of mounds so that mounds remain undisturbed. The colony will move the queen to safety if mounds are disturbed. See Table 2.

\section{SCALE}

Scale insects injure blueberries by sucking plant sap, inserting their mouthparts into a plant and remaining immobile throughout their lives. Signs of infestation are leaf yellowing (chlorosis), defoliation, fruit drop, sooty mold, branch dieback, or plant death. Soft scales, Coccidae, secrete a waxy covering over the body. They also secrete a large amount of sugary waste (honeydew) resulting in sooty mold, which can interfere with photosynthesis and slow plant growth. Of the soft scales, Indian Wax scale, Ceroplastes ceriferus (Fabricius), is the most prolific on blueberries in Florida. See Table 2 and EDIS publication ENY-411, "Insect Management in Blueberries in the Eastern United States" (https://journals.flvc.org/edis/article/view/116379).

\section{Prebloom through Green Tip (Leaf Buds) and Pink Bud (Flower Buds) PHOMOPSIS CANE AND TWIG BLIGHT}

Phomopsis cane and twig blight is a fungal disease caused by Phomopsis vaccinii, which is spread to uninfected plants by wind and rain. Characteristic symptoms are dark-brown lesions on fruiting twigs (often surrounding floral buds), dieback of young twigs, and shriveling of flower and fruit clusters on diseased stems. Dying tissue may spread down the twig until most of the flower buds on an individual twig die. Shriveling of flowers and fruit clusters may appear similar to Botrytis damage. Control measures include fungicide applications and pruning out infected twigs. See Table 1.

\section{BLUEBERRY GALL MIDGE}

See discussion above.

\section{0\%-20\% Bloom through $80 \%-90 \%$ Bloom}

\section{ALTERNARIA AND ANTHRACNOSE FRUIT ROTS}

Alternaria fruit rot occurs most frequently when fruit is not timely harvested and remains on the bush for too long. Symptoms include dark-green to black sporulation on ripe fruit and sunken areas near the calyx end of the berry. In postharvest storage, green to gray fuzzy growth may appear on infected fruit, especially if the berries have remained wet or were not properly cooled. Preventive fungicide applications can be made to help minimize disease development.

Anthracnose fruit rot is also referred to as "ripe rot." Infection may occur as early as bloom, with symptoms 
appearing as the fruit begins to ripen, including shriveling, development of sunken lesions, soft, rotted fruit, and eruption of orange- or salmon-colored spore masses on the blossom end of the fruit. In some cases, symptoms do not appear until after the fruit is harvested and stored. Fungicide applications from bloom through harvest prevent significant ripe rot losses most years when coupled with frequent hand-harvesting and rapid-cooling practices that are standard for southern highbush blueberry growers in Florida. Preharvest fungicides are especially important in years where there is a high incidence of disease in the field coupled with warm, wet weather, which can promote disease development. See Table 1 and EDIS publication PP337, "Anthracnose on Southern Highbush Blueberry" (https://edis.ifas.ufl.edu/publication/PP337).

\section{BOTRYTIS FLOWER BLIGHT}

Botrytis blossom blight, caused by the fungus Botrytis cinerea, most commonly infects and blights wounded or senescent plant tissues. As a blueberry bush blooms, corollas (the fused petal of the flowers) senesce and become quite susceptible to infection. Ideally the corolla should drop from the flower after pollination but before senescence occurs. Frost damage on tender new growth may wound the plant, delay petal drop, and facilitate infection by the fungus. The development of Botrytis blight, like many other foliar fungal diseases, is highly dependent on environmental conditions. During bloom, periods of low temperatures combined with extended periods of high relative humidity result in more than 24 hours of leaf wetness and increase likelihood of significant disease development. If the blight continues, an entire cluster of berries can be aborted. When disease is severe, berry reduction can become economically important. Infected berries are sometimes deformed and may develop further rot if environmental conditions later become favorable for disease. After pollination of a flower and drop of the corolla, the risk of infection of the developing fruit is reduced. Economic loss due to Botrytis can be minimized by limited use of irrigation for freeze protection and judicious fungicide applications. See Table 1 and EDIS publication PP198, "Botrytis Blossom Blight on Southern Highbush Blueberry” (https://edis.ifas.ufl.edu/publication/ PP119).

\section{FLOWER THRIPS}

These are small insects (i.e., 1/16 of an inch in length), yellowish to orange in color with fringed wings. Flower thrips damage blueberry flowers in two ways. Larvae and adults feed on all parts of the flowers, including ovaries, styles, petals, and developing fruit. This feeding damage can reduce the quality and quantity of the fruit produced.
Females damage the fruit when they lay their eggs inside flower tissues. The newly hatched larvae bore holes in the flower tissues when they emerge. Flower thrips can be very damaging to flower buds and blooms. Thrips numbers typically increase dramatically as corollas open and bloom progresses. Determining when or if blueberries should be treated for thrips is difficult. Blueberries are a pollinationsensitive crop, and careless use of insecticides and subsequent bee kill can easily impair pollination and ruin fruit set. Only selected insecticides (Delegate ${ }^{\circledast}$ ) should be used during bloom. If Delegate ${ }^{\varpi}$ is used, the insecticide should be applied in the early morning or late evening and be given 3 hours of drying time before bees are allowed to forage on the crop. To measure treatment thresholds for southern highbush and rabbiteye blueberries, begin sampling bloom clusters as soon as the flower begins to open. Sample four to five areas in a 1-acre block by placing a white sheet under a flower cluster and tapping lightly. Count the number of flowers and count the number of thrips dislodged from the flower cluster. If you average more than four thrips (southern highbush) or three thrips (rabbiteye) per flower, some type of management is recommended. Alternatively, two white sticky traps could be used to monitor a 5-acre block (one on the border and one in the center). If you have more than 80-100 thrips (southern highbush) or 60-70 thrips (rabbiteye), then some type of management tactic is needed. Assail ${ }^{\oplus}$ and Apta ${ }^{\oplus}$ are the material of choice until 5 days prebloom. See Table 2.

\section{Petal Fall through One Month after Bloom ALTERNARIA AND ANTHRACNOSE FRUIT ROTS}

See discussion above.

\section{PHYTOPHTHORA ROOT ROT}

See discussion above.

\section{BLUEBERRY GALL MIDGE}

See discussion above.

\section{CRANBERRY FRUITWORM, CHERRY FRUITWORM, AND PLUM CURCULIO}

Review field histories and scout fields for fruitworms and plum curculio to determine if and when spraying is needed. In Florida production areas, plum curculio has not been found to be a pest of southern highbush and rabbiteye blueberries. Fields with a history of infestation should be sprayed at least twice on a 7-to-14-day interval, beginning immediately after bloom. Check for fruitworms twice a week from full bloom until 4 weeks after petal fall. Examine fruit clusters for tiny pin-sized holes in berries and for 
frass and premature ripening in more mature fruit. Break berries open to look for larvae and damage. Early varieties are normally infested first. Control will be best when these insects are sprayed early in the infestation period. See Table 2.

\section{Preharvest Fruit}

\section{ALTERNARIA AND ANTHRACNOSE FRUIT ROTS}

See discussion above.

\section{Harvested Fruit}

\section{ALTERNARIA AND ANTHRACNOSE FRUIT ROTS}

See discussion above. Pre- and postharvest rots can be greatly reduced by timely, complete harvest of all ripe fruit on the bush, followed by rapid postharvest cooling. For hand-harvested highbush and southern highbush cultivars, harvest all ripe berries on the bush every 7 days or less. Rabbiteye cultivars should be clean-harvested every 10-14 days. Postharvest cooling is critical and is best accomplished through the use of partial-vacuum or forcedair systems that use fans to pull cold air through stacks of palletized fruit. See Table 1.

\section{BLUEBERRY MAGGOT}

Blueberry maggot $(\mathrm{BBM})$ is only a problem for growers north of the Lake City and Live Oak areas. Growers in Gainesville and south of Gainesville should not experience any problems with blueberry maggot. Blueberry maggot is a late-season pest. If berries are infested with BBM, a whitish maggot will appear in the fruit at harvesting. The adult fly that lays the eggs can be monitored by hanging yellow sticky traps (baited with ammonium acetate) within the bush canopy, at least one per cultivar. Trap catches indicate when adults are present. Traps should be hung in the planting when berries begin to turn from full green to the greenish-pink stage. See your county Extension agent for identification pictures and further reference. If your planting has a history of BBM infestation, spray as soon as adults are trapped. Once spraying for BBM begins, it is very important to spray every 7-14 days until all the fruit has been harvested. Materials and spray intervals are listed below. All growers in Florida who are shipping blueberries to Canada or the United Kingdom must comply with appropriate guidelines for scouting, spraying, and postharvest inspection of berries, including a protocol for cooking samples of harvested fruit to test for the presence of the maggot in berries. The Canadian protocol states that blueberries must be certified maggot-free to enter Canada. See Table 2.

\section{DIAPREPES (CITRUS ROOT WEEVIL)}

Diaprepes larvae damage blueberry plants by feeding on the roots, including channeling and holes in the roots and feeding injury and girdling near the crown of the plant. Note that this damage is frequently observed some period of time after the larvae begin to feed on the roots, and at that point damage near the crown can appear similar to the effects of root girdling or mechanical wounding and abrasion. These injuries can kill or cause serious decline in blueberry plants and may also create an entry point for Phytophthora, causing a root rot infection. Management and control should target both the adult and larval stages. Control for adults consists of foliar insecticide sprays every 10-14 days when adults are active, beginning when 3 or more adults are found within 1-acre blocks. Larvae can be managed with insecticides either by directly drenching the soil area beneath the plant canopy or by applying them through drip or microjet irrigation systems. In addition, entomopathogenic nematodes may have potential for controlling root weevil larvae in blueberry. See Table 2 and EDIS publication ENY-999, "Diaprepes Root Weevil on Southern Highbush Blueberry in Florida" (https://edis.ifas. ufl.edu/publication/IN1241).

\section{FLATHEADED BORERS}

Flatheaded borers are a species of beetle in the Chrysobothris genus. The larvae tunnel through plant canes, ultimately killing the cane and acting as an entry point for disease. It is possible that adult beetles are attracted to stressed or damaged blueberry canes, with adult females laying eggs on the injured area, and larvae excavating tunnels just beneath the bark. This is a relatively new pest in blueberry, and research is ongoing regarding its life cycle, monitoring and trapping protocols, and control measures. See Table 2.

\section{SPOTTED WING DROSOPHILA}

Spotted Wing Drosophila (SWD) have been caught in all principal blueberry counties in Florida. Adults lay eggs in ripening blueberries, and larvae develop inside the berry, making the fruits soft and unmarketable. Adults can be monitored by placing traps in blueberry bushes. Traps can be made from plastic cups and baited with yeast sugar water. Traps should be placed within the canopy of the blueberry bush and not in direct sunlight. A number of insecticides have recently been registered for control of spotted wing drosophila. See Table 2 and EDIS publication ENY-861, "Spotted Wing Drosophila in Florida Berry Culture” (https://edis.ifas.ufl.edu/publication/IN839). 


\section{Postharvest Plants}

\section{ALGAL STEM BLOTCH}

Algal stem blotch is a blueberry disease caused by the parasitic green alga Cephaleuros virescens Kunze, and it has become a significant disease on southern highbush blueberries in Florida. The alga is thought to enter the plant through natural wounds and openings, through pruning cuts, or by direct penetration of the cuticle. Early symptoms include small red blotches or lesions on green juvenile stems, with lesions expanding to form irregular cankers that can encircle canes. Bright-orange felt-like mats or tufts of algal growth appear from the lesions on young stems and older cane surfaces during summer and early fall when conditions are hot and humid. Leaves on symptomatic canes bleach white to pale yellow, and growth of the entire plant can be severely stunted as the disease advances. Leaf yellowing tends to occur on a few canes of each plant and is less uniform and blotchier than symptoms of nutritional deficiency. Algal stem blotch can lead to increased susceptibility to Botryosphaeria stem blight, in some cases leading to plant death. Plants that are stressed by abiotic or biotic factors are more susceptible to infection and subsequent disease development. To date, no systemic pesticide products have been found that will kill the algae living underneath the plant epidermis. Spray applications of copper-containing fungicides can help to reduce algal sporulation and protect healthy canes from infection for a few days after application. However, these applications do not impact existing symptoms or eradicate the disease. See Table 1 and EDIS publication PP344, "Algal Stem Blotch in Southern Highbush Blueberry in Florida" (https://edis.ifas. ufl.edu/publication/PP344).

\section{ANTHRACNOSE LEAF SPOT, RUST, SEPTORIA, AND TARGET SPOT}

Anthracnose, Septoria, rust, and target spot can cause premature defoliation, resulting in poor bud development and subsequent loss of yield. Fungicide timing for leaf spots varies across the state and by specific disease. Septoria can occur prior to harvest through late spring. Anthracnose leaf spots and target spots generally start postharvest and persist through summer. Rust is a problem in all Florida production areas. On susceptible varieties, rust can prematurely defoliate plants. Where leaves are not dropped in winter, rust can carry over on the previous year's foliage and can cause rust problems in early spring as well. Bravo Weather Stik ${ }^{\oplus}$ is labeled for control of both rust and Septoria leaf spots; this chlorothalonil product makes an excellent rotation partner for the strobilurin-containing products Abound ${ }^{\circledast}$ or Pristine ${ }^{\oplus}$. However, Bravo Weather
Stik $^{\oplus}$ can only be used after harvest because chlorothalonil will damage fruit. See Table 1 and EDIS publication PP348, "Florida Blueberry Leaf Disease Guide" (https://edis.ifas.ufl. edu/publication/PP348).

\section{AZALEA CATERPILLAR}

The azalea caterpillar, Datana major, can be found in Florida from late summer to early fall on blueberries. Immature caterpillars are around $1 / 2$ inch long and reddish to brownish-black with yellow and white stripes. Mature caterpillars are about 2 inches long and black with yellow to white stripes and a reddish head and legs. If left uncontrolled, a significant infestation can defoliate much of a plant. Although these caterpillars seldom kill the plants they feed on, the stress caused by defoliation can reduce flowering or fruiting the following spring. See Table 2.

\section{BACTERIAL SCORCH (XYLELLA)}

Bacterial leaf scorch, caused by Xylella fastidiosa, was first identified on blueberry in 2006 in the southeastern United States. Symptoms begin as a marginal-irregular leaf scorch, which may appear similar to symptoms of bacterial wilt or drought stress. Symptoms are initially observed on leaves attached to individual stems or groups of stems on one side of a plant. Plant vigor is reduced, stems and twigs of some varieties such as 'Meadowlark' turn a distinctive yellow color, and the plants eventually die. Diseased plants are typically observed randomly scattered throughout a field, rather than in distinct circles or groups within a row. Infected plants should be removed and destroyed. This bacterial pathogen is vectored by insects called sharpshooters and spittle bugs, including the glassy-winged sharpshooter. Infection levels may be reduced by controlling the vector with suggested insecticides.

\section{BACTERIAL WILT (RALSTONIA)}

Symptoms of bacterial wilt are similar to those of bacterial scorch, exhibiting signs of drought stress such as wilting and marginal leaf burn. Infected plants may also be more susceptible to developing severe symptoms of other stress diseases, such as Botryosphaeria stem blight, and therefore may show symptoms of both diseases. Crowns of plants with bacterial wilt have a mottled discoloration or light-brown to silvery purple blotches with poorly defined borders (distinct from the discoloration associated with stem, which is typically pie-piece-shaped and pecan brown in color). Wood chips floated in water from the crowns of plants with bacterial wilt will stream bacterial ooze (unlike plants with bacterial scorch or stem blight). Ralstonia can be spread easily in water, in soil, or through infected plant material, and infected plants may not initially show 
symptoms. Ralstonia can survive for years in soil, slowly spreading down and across rows of blueberry, leaving large circular patches of dead and dying plants. Where the bacterium is detected, remove and burn or deep-bury infected plants. Then, use soil drenches of products with phosphorous acids or salts to help protect surrounding plants or any replants from infection. See Table 1 and EDIS publication PP332, "Bacterial Wilt of Southern Highbush Blueberry Caused by Ralstonia solanacearum" (https://edis. ifas.ufl.edu/publication/PP332).

\section{BLUEBERRY BUD MITE}

The blueberry bud mite is an eriophyid mite so tiny (i.e., 1/125 inch long) that it cannot be seen without magnification. Blueberry bud mite is an occasional pest in well-established blueberries in Florida. Bud mite injury is often confused with frost damage and may become more visible in late spring. In early spring, infested plants exhibit stunted, succulent, fleshy, closely packed, reddish, and rosetted buds, which may dry up and often fail to open. Bloom on infested plants is reduced. Affected berries are small and rough and may have small, reddish pimples or blisters on the fruit surface. Sanitation by aggressive, timely pruning of infested branches can be helpful. Mechanical topping (i.e., mowing old fruiting twigs) immediately after harvest greatly reduces bud mite incidence the following year. Bushes that may be infested with blueberry bud mite should never be used for propagation. The application of horticultural oil immediately after harvest can help in the control of blueberry bud mite. A new miticide, Magister ${ }^{\circledR}$ (fenazaquin) was recently registered in blueberries and should provide some protection against eriophyids. The insecticide Apta ${ }^{\oplus}$ (tolfenpyrad) should also provide protection against eriophyids. Blueberry bud mites belong to this group. Conventional insecticides such as pyrethroids have miticidal effects and can be used to help reduce bud mite infestation. See Table 2 and EDIS publication ENY-858, "Blueberry Bud Mite (Acalitus vaccini (Keifer) on Southern Highbush Blueberry in Florida" (https://edis.ifas.ufl.edu/ publication/IN844).

\section{CHILLI THRIPS}

Chilli thrips are becoming a more pronounced problem in blueberry. Adults feed on blueberries in late spring to early summer shortly after the bushes are pruned. Chilli thrips feed primarily on young leaves, causing leaf bronzing and shoot dieback. During heavy infestation, the edges around younger leaves and stems are eaten and leaf curling occurs. The chilli thrips are smaller than the flower thrips and are approximately 0.04 inches long with dark fringed wings and dark spots across the back of the abdomen. Insecticides that can be used to manage chilli thrips include Delegate ${ }^{\bullet}$ (spinetoram), Assail ${ }^{\bullet}$ (acetamiprid), Sivanto ${ }^{\circ}$ (flupyradifurone), and Apta ${ }^{\oplus}$ (tolfenpyrad). Conventional products that can be used to manage chilli thrips include Malathion and Sevin ${ }^{\circledast}$ (carbaryl). See Table 2 and EDIS publication ENY2053, "Chilli Thrips on Blueberries in Florida" (https://edis. ifas.ufl.edu/publication/IN1298).

\section{DIAPREPES (CITRUS ROOT WEEVIL)}

See discussion above.

\section{DIEBACK DISEASES OF SOUTHERN HIGHBUSH VARIETIES}

Most southern highbush varieties are hedged immediately after harvest. Hedging cuts can serve as an entry point for many stem pathogens. At the end of each day of hedging, application of broad-spectrum fungicides such as Captan mixed with Prophyt ${ }^{\circledR}$ may help reduce infection. Resistance to azoxystrobin has been confirmed for Anthracnose stem dieback in central Florida. Do not use Abound ${ }^{\circledR}$ as a standalone application where resistance is known, but tank-mix with Captan or Bravo. See Table 1 and EDIS publication PP347, "Botryosphaeria Stem Blight on Southern Highbush Blueberry in Florida" (https://edis.ifas.ufl.edu/publication/ PP347).

\section{FLATHEADED BORERS}

See discussion above.

\section{FLEA BEETLES}

The blueberry flea beetle can cause serious damage during the summer months. Blueberry flea beetle eggs, and possibly adults, overwinter in the leaf litter of blueberry fields. Eggs are very small and orange-yellow in color, and hatching coincides with leaf bud opening. Larvae migrate to the foliage and feed on blossoms and leaf margins, giving the leaves a notched appearance. The larval stage takes 9-20 days to complete. Fully-grown larvae fall to the soil and pupate, with adults emerging approximately 15-28 days later. Adults are less than 0.25 inches in length, oval shaped, and a shiny copper bronze or metallic blue in color, and they chew small holes in the foliage. Adults mate and lay up to 200 eggs per female. The blueberry flea beetle has several generations per year in the southern United States. See Table 2 and EDIS publication ENY-411, "Insect Management in Blueberries in the Eastern United States" (https:// journals.flvc.org/edis/article/view/116379).

\section{IMPORTED FIRE ANTS}

See discussion above. 


\section{SPIDER MITES}

The southern red mite is the key spider mite pest attacking blueberry plants in Florida. Southern red mites primarily infest the lower side of the leaf, giving the leaf a bronzing appearance when the population is high. Southern red mites also produce a protective web made of silk over the infested surface to protect them from predators. The underside of leaves should be closely examined with a 10x hand lens for adults, shed skins, and webbing. Tapping foliage onto a sheet of white paper can also be used to find adult mites. A few miticides, including fenazaquin (Magister ${ }^{\circledR}$ ), fenpyroximate $\left(\right.$ Portal $^{\circledR}$ ) and acequinocyl (Kanemite ${ }^{\circledast}$ ), have recently been labelled for spider mites. See Table 2 and EDIS publication ENY-1006, "Mite Pests of Southern Highbush Blueberry in Florida” (https://edis.ifas.ufl.edu/ publication/IN1284).

\section{WHITE GRUBS (GRUBS OF ASIATIC GARDEN BEETLE, EUROPEAN AND MASKED CHAFER, AND ORIENTAL BEETLE)}

White grubs are the larval form of certain beetle species, such as the masked chafer. They feed on blueberry roots, and damaged plants have the appearance of drought stress. It may take a number of years for larvae numbers to increase to a damaging level, although feeding injury on young plants can quickly result in symptoms and plant death. Masked chafer larvae are up to one inch long, with whitish bodies and brown head and legs. See Table 2.

\section{YELLOW-NECKED CATERPILLAR}

Yellow-necked caterpillars feed on the foliage of blueberry plants. Their bodies are covered with long, fine whitish hairs. The head is black, the area behind the head is yellow, and the body is covered with fine white hairs. Feeding by newly hatched caterpillars can skeletonize the foliage, leaving only the large leaf veins. In significant infestations, plant defoliation can occur. This can be minimized by pruning out infested stems. See Table 2.

\section{Nonproblematic Diseases in Florida}

Note: The diseases listed below have not been problematic for Florida growers to date.

\section{MUMMY BERRY}

Mummy berry is currently not an important disease of southern highbush blueberry in Florida. However, the disease is a major issue in production areas north of Florida. Florida growers concerned about potential mummy berry problems are encouraged to contact your local UF/IFAS Extension office for diagnostic confirmation and additional information (http://sfyl.ifas.ufl.edu/find-your-local-office/).

\section{EXOBASIDIUM FRUIT AND LEAF SPOT}

The fungal pathogen Exobasidium causes green to white spots on leaves and fruits that sporadically impact yield and fruit quality in Georgia and other parts of the Southeast. The disease has only been a problem in the northernmost production areas in Florida to date. Specific dormant applications have been shown in Georgia to help reduce exobasidium but are not recommended for Florida production. Florida growers who suspect exobasidium should contact their local UF/IFAS Extension office for confirmation and management options (http://sfyl.ifas.ufl. edu/find-your-local-office/).

\section{VIRAL BLUEBERRY DISEASES}

Diseases caused by viruses that include blueberry shoestring virus, blueberry scorch virus, and blueberry shock virus (among others) impact highbush blueberry production in northern states but are not known to occur in Florida production. Blueberry red ringspot virus and blueberry necrotic ring blotch virus occur in Florida but do not significantly impact production. Florida growers who suspect viral blueberry diseases should contact their local UF/IFAS Extension office for confirmation and management options (http://sfyl.ifas.ufl.edu/find-your-local-office/).

\section{Commonly Recognized Stages of Flower Bud Development for Southern Highbush Blueberry}

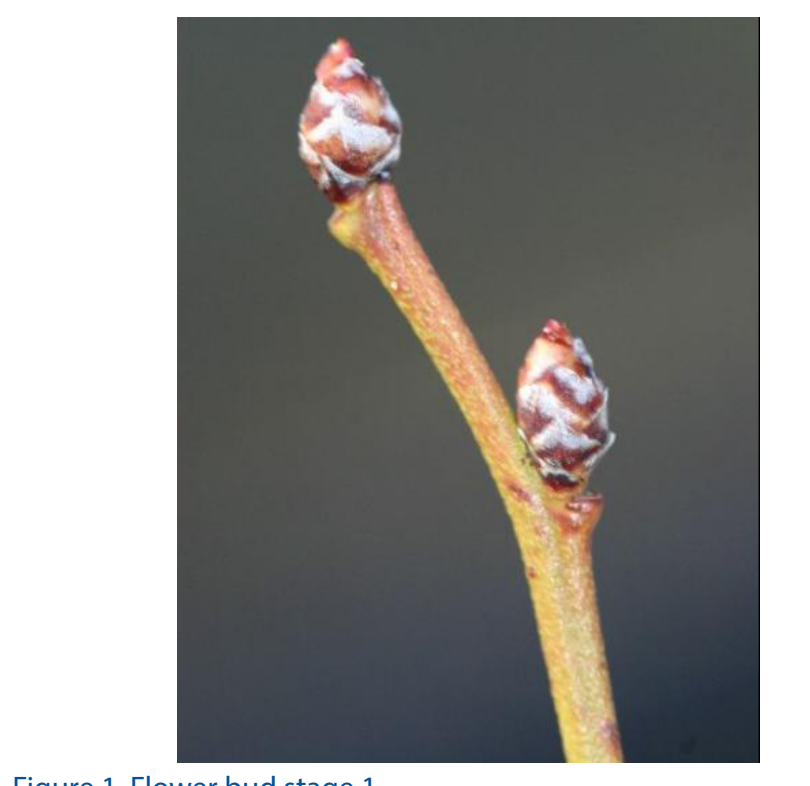

Figure 1. Flower bud stage 1.

Credits: Jeff Williamson 


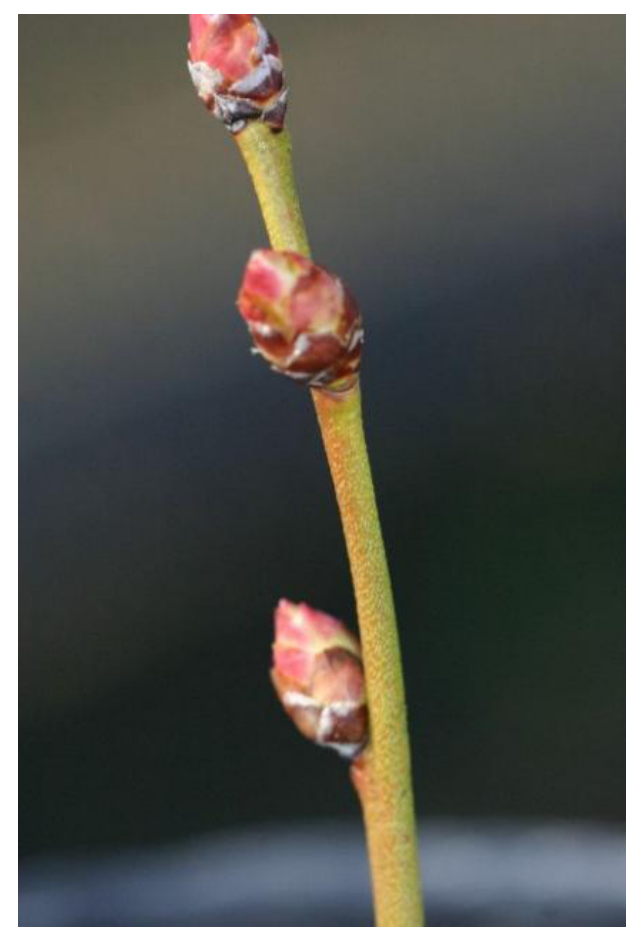

Figure 2. Flower bud stage 2 .

Credits: Jeff Williamson

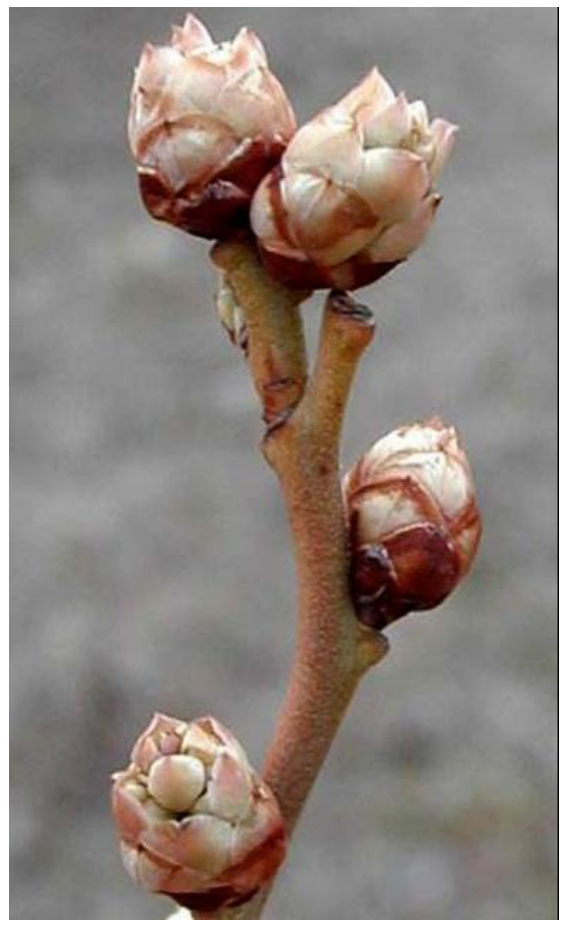

Figure 3. Flower bud stage 3.

Credits: Mark Longstroth (Michigan State University Extension)

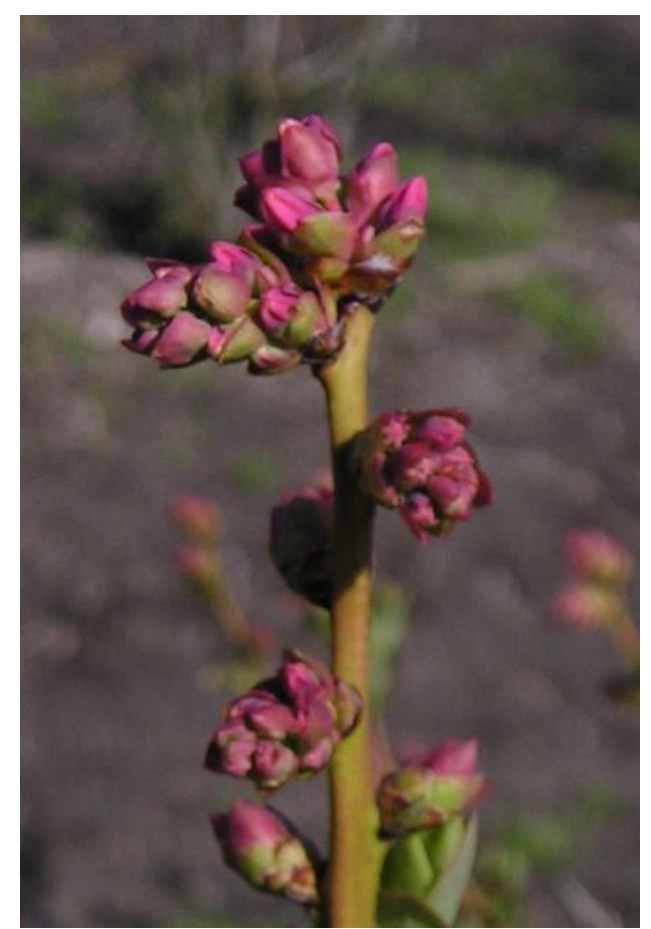

Figure 4. Flower bud stage 4.

Credits: Mark Longstroth (Michigan State University Extension)

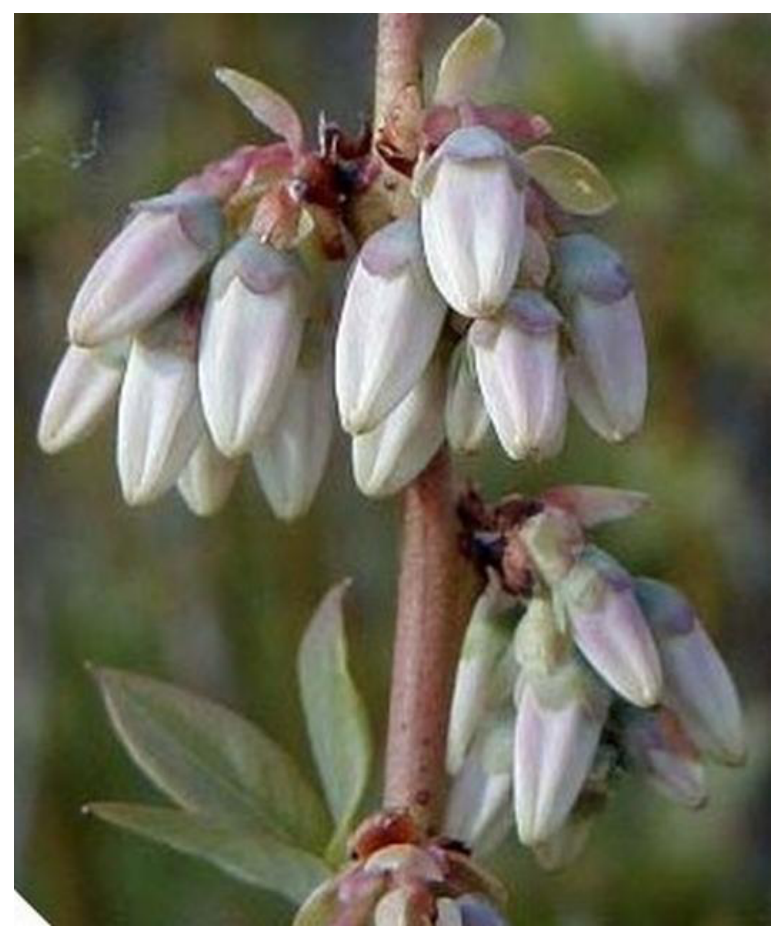

Figure 5. Flower bud stage 5 .

Credits: Mark Longstroth (Michigan State University Extension) 


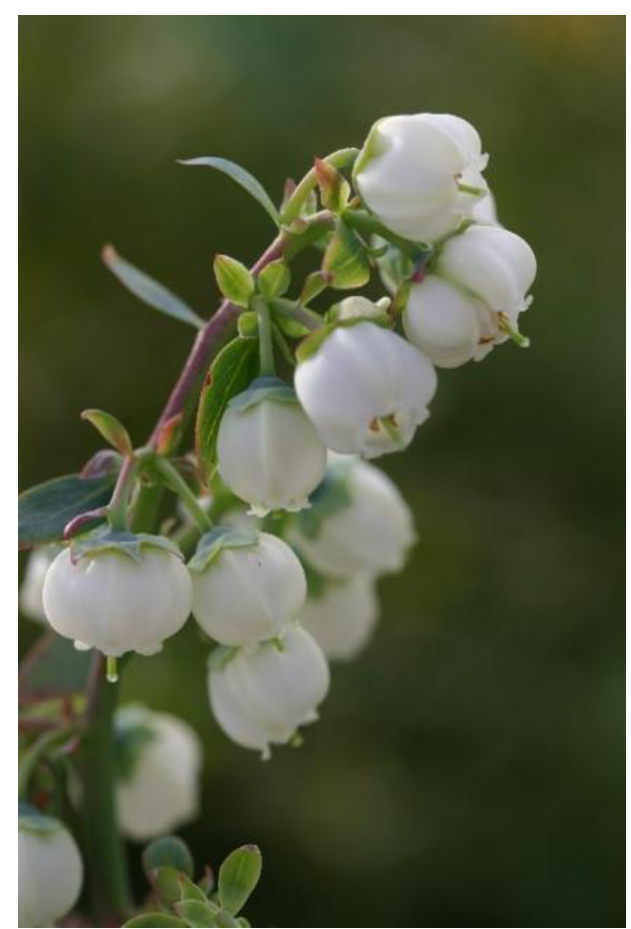

Figure 6. Flower bud stage 6.

Credits: Jeff Williamson

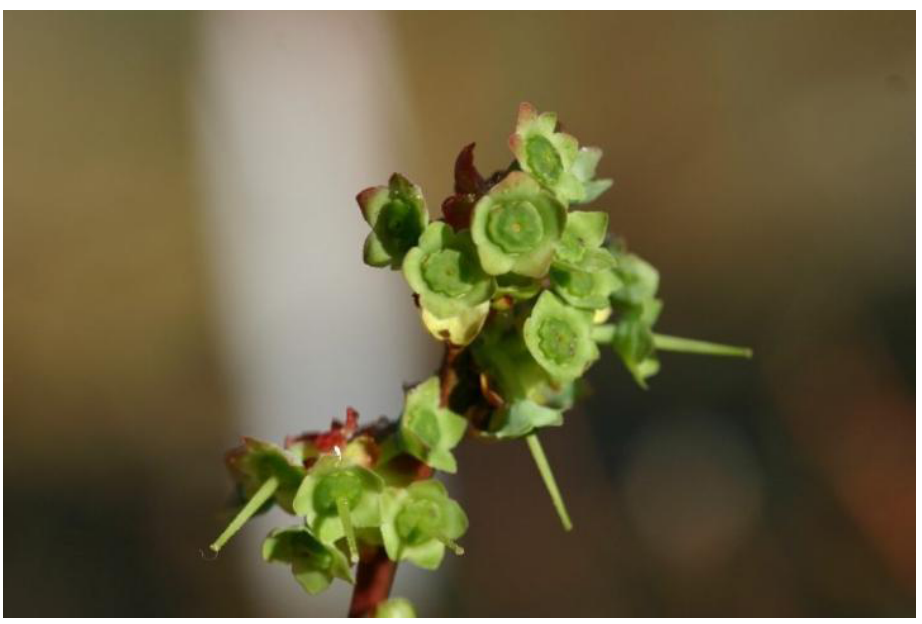

Figure 7. Flower bud stage 7.

Credits: Jeff Williamson

\section{Management Option Tables}

All the following tables list registered pesticides that should be integrated with other pest management methods. Additional information on integrated pest management methods can be requested from UF/IFAS Extension horticulture or agriculture agents. A list of local UF/IFAS Extension offices is at available at http://sfyl.ifas.ufl.edu/ find-your-local-office/.

This publication was adapted for Florida from the Southeast Regional Blueberry Integrated Management Guide, available at https://smallfruits.org/files/2021/01/2021-BlueberrySpray-Guide.pdf. Thus, major contributions were made by the original editors: Commodity Editor - Hannah Burrack
(North Carolina State University); Section Editors - Entomology: Hannah Burrack (North Carolina State University), Aaron Cato (University of Arkansas), Frank Hale (University of Tennessee), Ash Sial (University of Georgia), Doug Pfeiffer (Virginia Tech) Horticulture: Eric Stafne (Mississippi State University) Pathology: Bill Cline (North Carolina State University), Mary Helen Ferguson (Louisiana State University), Rebecca Melanson (Mississippi State University), Jonathan Oliver (University of Georgia), Raj Singh (Louisiana State University), Weed Science: Mark Czarnota (University of Georgia), Katie Jennings (North Carolina State University) Vertebrate Management: Michael T. Mengak (University of Georgia), David Lockwood (University of Tennessee) Pesticide Stewardship and Safety: Ash Sial (University of Georgia); Senior Editors - Phil Brannen (University of Georgia) Bill Cline (North Carolina State University).

Additional contributions by Allen Straw (Virginia Tech University), Scott Nesmith and Harald Scherm (University of Georgia), Steve Bost (University of Tennessee), Phil Harmon (University of Florida), Charlie Johnson (Louisiana State University), Carol Hicks (N.C. State University), and Kathryn Fontenot (Louisiana State University).

Recommendations are based on information from the manufacturers' labels and performance data from research and Extension field tests.

Because environmental conditions and grower application methods vary widely, suggested use does not imply that performance of the pesticide will always conform to the safety and pest control standards indicated by experimental data.

This publication is intended for use only as a guide. Specific rates and application methods are on the pesticide label, and these are subject to change at any time. Always refer to and read the pesticide label before making any application! The pesticide label supersedes any information contained in this guide, and it is the legal document referenced for application standards.

\section{Pesticide Emergencies}

Poisonings: $1-800-222-1222$

The above number automatically connects you with a local Poison Control Center from anywhere in the United States.

Pesticide spills or other emergencies: $1-800-424-9300$ (24 hours) CHEMTREC 
Be prepared-visit www.chemtrec.com now for a listing of the information you will be asked to provide in the event of a chemical spill emergency.

Spills on public roads: In many cases, you can call CHEMTREC at 1-800-424-9300, call 911, or call the Florida Hazardous Material Planning Section, 1-800-320-0519 (cell: call *FDCA)

Environmental emergencies (contamination of waterways, fish kills, bird kills, etc.): Florida Department of Community Affairs Response Team, 1-800-320-0519

\section{Pesticide Safety and Label Interpretation Resources:}

- Federal Regulations Affecting Use of Pesticides (https:// edis.ifas.ufl.edu/pi168)

- Pesticide Labeling (https://edis.ifas.ufl.edu/entity/topic/ pesticide_labeling)

- Toxicity of Pesticides (https://edis.ifas.ufl.edu/pi008)

Sprayer Calibration: Sprayer calibration is very important. Sprayers should be calibrated often to keep from accidentally using excess pesticides because of nozzle wear, speed increases, and other calibration problems. Failing to calibrate often costs money, may cause crop damage, and is unsafe. Below is a list of online resources that deal with calibration of pesticide applicators.

- Calibration of Herbicide Applicators (https://edis.ifas.ufl. edu/wg013)

- Calibration of Airblast Sprayers (https://edis.ifas.ufl.edu/ ae238)

- Pesticide Calibration Formulas and Information (https:// ufdc.ufl.edu/IR00004194/00001)

POLLINATOR PROTECTION (from the 2021 Southeastern Blueberry Integrated Management Guide)

Before making insecticide applications, monitor insect populations to determine if treatment is needed. If pesticide (fungicide or insecticide) application is necessary:

1. Use selective pesticides to reduce risk to pollinators and other nontarget beneficial insects.

2. Read and follow all pesticide label directions and precautions. The label is the law! The EPA now requires the addition of a "Protection of Pollinators" advisory box on certain pesticide labels. Look for the bee hazard icon in the Directions for Use and within crop-specific sections for instructions to protect bees and other insect pollinators.

3. Minimize infield exposure of bees to pesticides by avoiding applications when bees are actively foraging in the crops. Bee flower visitation rate is highest in early morning. Apply pesticides in the late afternoon or early evening to allow for maximum residue degradation before bees return the next morning. Bee foraging activity is also dependent upon time of year (temperature) and stage of crop growth. The greatest risk of bee exposure is during bloom.

4. Minimize off-target movement of pesticide applications by following label directions to minimize off target movement of pesticides. Do not make pesticide applications when the wind is blowing towards bee hives or off-site pollinator habitats. 
Table 1. Disease Management Options

\begin{tabular}{|c|c|c|c|c|c|c|}
\hline Disease & $\begin{array}{l}\text { Management } \\
\text { Options }\end{array}$ & $\begin{array}{l}\text { Amount of } \\
\text { Formulation } \\
\text { per Acre }\end{array}$ & $\begin{array}{c}\text { Effectiveness } \\
(\text { Least }=+ \text { to } \\
\text { Most }=+++++)\end{array}$ & $\begin{array}{c}\text { Restricted } \\
\text { Entry Interval } \\
\text { (REI) }\end{array}$ & $\begin{array}{l}\text { Postharvest } \\
\text { Interval (PHI) }\end{array}$ & Comments \\
\hline \multirow[t]{2}{*}{$\begin{array}{l}\text { Algal stem } \\
\text { blotch }\end{array}$} & Kocide $^{\circledR} 3000$ & $1.75-3.5 \mathrm{lb}$ & ++ & $48 \mathrm{~h}$ & 0 days & $\begin{array}{l}\text { Make applications after harvest } \\
\text { on a monthly interval following } \\
\text { bacterial canker use instructions. } \\
\text { Ensure good cane coverage and } \\
\text { canopy penetration. Do not mix } \\
\text { with Aliette }{ }^{\circledR} \text {, any phosphite } \\
\text { fungicide, or any acidifying agents. } \\
\text { Do not exceed } 28 \text { lb per acre per } \\
\text { year. Copper products provide } \\
\text { preventive management of algal } \\
\text { stem blotch only. }\end{array}$ \\
\hline & $\begin{array}{l}\text { other copper } \\
\text { products }\end{array}$ & & & & & $\begin{array}{l}\text { Many formulations and products } \\
\text { that contain copper are labeled for } \\
\text { use on blueberry at various rates } \\
\text { and application intervals. Carefully } \\
\text { follow all label instructions for any } \\
\text { product to avoid phytotoxicity. } \\
\text { Algal stem blotch is not likely to } \\
\text { specifically appear on the label, } \\
\text { but these products can be used as } \\
\text { long as the crop and site is on the } \\
\text { label. }\end{array}$ \\
\hline \multirow[t]{6}{*}{$\begin{array}{l}\text { Anthracnose } \\
\text { (ripe rot) and } \\
\text { Alternaria rots }\end{array}$} & $\begin{array}{l}\text { Azoxystrobin } \\
\left(\text { Abound }^{\circledR}\right)\end{array}$ & $6.2-15.4 \mathrm{fl} \mathrm{oz}$ & +++++ & $4 \mathrm{~h}$ & 0 days & $\begin{array}{l}\text { Resistance to this fungicide in } \\
\text { the ripe rot pathogen is common } \\
\text { in central Florida. Use a Captan } \\
\text { product in a tank mix where } \\
\text { resistance is known. Subsequent } \\
\text { applications can be made at } \\
\text { 7-to-14-day intervals. Do not } \\
\text { apply more than two sequential } \\
\text { applications before switching to } \\
\text { a fungicide with another mode of } \\
\text { action (e.g., Switch }{ }^{\circledast} \text { ). Do not apply } \\
\text { more than } 1.44 \text { qt per acre per } \\
\text { season. }\end{array}$ \\
\hline & $\begin{array}{l}\text { Cyprodinil + } \\
\text { fludioxonil } \\
\text { (Switch }{ }^{\circledR} 62.5 \text { WG) }\end{array}$ & $11-14 \mathrm{oz}$ & +++++ & $12 \mathrm{~h}$ & 0 days & $\begin{array}{l}\text { Applications can be made at 7-to- } \\
\text { 10-day intervals when conditions } \\
\text { warrant. Do not apply more than } \\
56 \text { oz of product per acre per year. } \\
\text { Make no more than two sequential } \\
\text { applications before using another } \\
\text { fungicide with a different mode of } \\
\text { action. }\end{array}$ \\
\hline & $\begin{array}{l}\text { Pyraclostrobin } \\
+ \text { boscalid } \\
\left.\text { (Pristine }^{\circledast}\right)\end{array}$ & $18.5-23 \mathrm{oz}$ & +++++ & $12 \mathrm{~h}$ & 0 days & $\begin{array}{l}\text { Resistance to this fungicide in } \\
\text { the ripe rot pathogen is common } \\
\text { in central Florida. Use a Captan } \\
\text { product in a tank mix where } \\
\text { resistance is known. Do not mix } \\
\text { Pristine }{ }^{\circledR} \text { with anything other than } \\
\text { Captan. }\end{array}$ \\
\hline & $\begin{array}{l}\text { Ziram (Ziram } \\
\text { 76DF) }\end{array}$ & $3 \mathrm{lb}$ & ++ & $48 \mathrm{~h}$ & \% 30 days & $\begin{array}{l}\text { Do not apply later than } 3 \text { weeks } \\
\text { after full bloom. }\end{array}$ \\
\hline & $\begin{array}{l}\text { Captan (Captan } \\
50 \text { WP) }\end{array}$ & $5 \mathrm{lb}$ & +++ & $48 \mathrm{~h}$ & 0 days & $\begin{array}{l}\text { Do not apply more than } 70 \mathrm{lb} \text { per } \\
\text { acre per crop year. }\end{array}$ \\
\hline & $\begin{array}{l}\text { Captan (Captan } \\
\left.4 L^{\circledast}\right)\end{array}$ & $2 \mathrm{qt}$ & +++ & $48 \mathrm{~h}$ & 0 days & $\begin{array}{l}\text { Do not apply more than } 35 \text { qt per } \\
\text { crop year. }\end{array}$ \\
\hline
\end{tabular}




\begin{tabular}{|c|c|c|c|c|c|c|}
\hline Disease & $\begin{array}{l}\text { Management } \\
\text { Options }\end{array}$ & $\begin{array}{l}\text { Amount of } \\
\text { Formulation } \\
\text { per Acre }\end{array}$ & $\begin{array}{l}\text { Effectiveness } \\
\text { (Least }=+ \text { to } \\
\text { Most }=+++++)\end{array}$ & $\begin{array}{l}\text { Restricted } \\
\text { Entry Interval } \\
\quad \text { (REI) }\end{array}$ & $\begin{array}{l}\text { Postharvest } \\
\text { Interval (PHI) }\end{array}$ & Comments \\
\hline & $\begin{array}{l}\text { Fluazinam } \\
\left.\text { (Omega }{ }^{\circledR} 500 \mathrm{~F}\right)\end{array}$ & $1.25 \mathrm{pt}$ & $?$ & $12 \mathrm{~h}$ & 30 days & $\begin{array}{l}\text { Do not use more than } 7.5 \mathrm{pt} \text { per } \\
\text { acre per season. Do not tank mix } \\
\text { with an adjuvant. }\end{array}$ \\
\hline & $\begin{array}{l}\text { Metconazole } \\
\left(\text { Quash }^{\circledR}\right)\end{array}$ & $2.5 \mathrm{oz}$ & $?$ & $12 \mathrm{~h}$ & 7 days & $\begin{array}{l}\text { Do not make more than three } \\
\text { applications per acre per crop year. } \\
\text { Alternate with a fungicide with } \\
\text { another mode of action. }\end{array}$ \\
\hline & 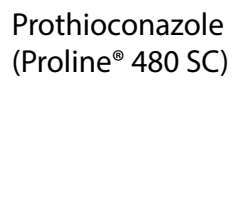 & $5.7 \mathrm{fl} \mathrm{oz}$ & $?$ & $12 \mathrm{~h}$ & 7 days & $\begin{array}{l}\text { Make up to } 2 \text { applications per year } \\
\text { on a } 7-10 \text { day schedule. A tank } \\
\text { mix with Captan is recommended } \\
\text { for resistance management and to } \\
\text { provide Botrytis suppression. }\end{array}$ \\
\hline & $\begin{array}{l}\text { Fluopyram + } \\
\text { pyrimethanil } \\
(\text { Luna } \\
\left.\text { Tranquility }^{\circledast}\right)\end{array}$ & 13.6-27 fl oz & $?$ & $12 \mathrm{~h}$ & 0 days & $\begin{array}{l}\text { Do not apply more than } 54.7 \mathrm{fl} \\
\text { oz per acre per year. Rotate to a } \\
\text { different fungicide group after } \\
\text { no more than } 2 \text { applications. } \\
\text { Reapplication interval is } 7 \text { to } 14 \\
\text { days. Only Luna Tranquility is } \\
\text { labeled by supplemental label for } \\
\text { blueberry in Florida. }\end{array}$ \\
\hline \multirow[t]{5}{*}{$\begin{array}{l}\text { Anthracnose, } \\
\text { septoria, } \\
\text { target spot, } \\
\text { and rust leaf } \\
\text { diseases }\end{array}$} & $\begin{array}{l}\text { Azoxystrobin } \\
\left(\text { Abound }^{\circledR}\right)\end{array}$ & $6.2-15.4 \mathrm{fl} \mathrm{oz}$ & ++++ & $4 \mathrm{~h}$ & 0 days & $\begin{array}{l}\text { Subsequent applications can be } \\
\text { made at 14-day intervals. Consider } \\
\text { tank mixing with Captan or Bravo. } \\
\text { When hedging is conducted } \\
\text { immediately following harvest, } \\
\text { this is a good time to consider an } \\
\text { application. Do not exceed } 1.44 \\
\text { qt per acre per season. Do not } \\
\text { apply more than two sequential } \\
\text { applications of Abound }{ }^{\circledR} \text { before } \\
\text { switching to a fungicide with } \\
\text { another mode of action. }\end{array}$ \\
\hline & $\begin{array}{l}\text { Pyraclostrobin } \\
+ \text { boscalid } \\
\left.\text { (Pristine }^{\circledast}\right)\end{array}$ & $18.5-23 \mathrm{oz}$ & ++++ & $12 \mathrm{~h}$ & 0 days & $\begin{array}{l}\text { No more than two sequential } \\
\text { applications of Pristine }{ }^{\circledast} \text { should } \\
\text { be made before alternating with } \\
\text { fungicides that have a different } \\
\text { mode of action. Do not apply more } \\
\text { than four applications of Pristine }{ }^{\circledast} \\
\text { per acre per crop year. }\end{array}$ \\
\hline & $\begin{array}{l}\text { Fenbuconazole } \\
\left.\text { (Indar }^{\circledast} 2 \mathrm{~F}\right)\end{array}$ & $2.0 \mathrm{oz}$ & +++ & $12 \mathrm{~h}$ & 30 days & $\begin{array}{l}\text { Do not make more than four } \\
\text { applications or apply more than } \\
8 \text { oz of Indar }{ }^{\circledast} 75 \text { WSP }(0.38 \mathrm{lb} \\
\text { active) per acre per year. Indar } \\
75 \text { WSP belongs to the sterol } \\
\text { demethylation inhibitor (DMI) class } \\
\text { of fungicides. Alternation with } \\
\text { fungicides of different classes is } \\
\text { recommended. }\end{array}$ \\
\hline & $\begin{array}{l}\text { Metconazole } \\
\left(\text { Quash }^{\circledast}\right)\end{array}$ & $2.5 \mathrm{oz}$ & +++ & $12 \mathrm{~h}$ & 7 days & $\begin{array}{l}\text { Do not make more than three } \\
\text { applications per acre per crop year. } \\
\text { Alternate with a fungicide with } \\
\text { another mode of action. }\end{array}$ \\
\hline & $\begin{array}{l}\text { Propiconazole } \\
\text { (Tilt }^{\oplus} \text { ) }\end{array}$ & $6.0 \mathrm{fl} \mathrm{oz}$ & +++ & $24 \mathrm{~h}$ & 30 days & $\begin{array}{l}\text { Tilt }^{\oplus} \text {, another DMI fungicide, may } \\
\text { be applied by ground or aerial } \\
\text { application (see label). Do not } \\
\text { apply more than } 30 \mathrm{fl} \text { oz per acre } \\
\text { per season. Tilt }{ }^{\circledast} \text { is more effective } \\
\text { when it dries ahead of a rain. }\end{array}$ \\
\hline
\end{tabular}




\begin{tabular}{|c|c|c|c|c|c|c|}
\hline Disease & $\begin{array}{l}\text { Management } \\
\text { Options }\end{array}$ & $\begin{array}{l}\text { Amount of } \\
\text { Formulation } \\
\text { per Acre }\end{array}$ & $\begin{array}{l}\text { Effectiveness } \\
\text { (Least }=+ \text { to } \\
\text { Most }=+++++)\end{array}$ & $\begin{array}{l}\text { Restricted } \\
\text { Entry Interval } \\
\text { (REI) }\end{array}$ & $\begin{array}{l}\text { Postharvest } \\
\text { Interval (PHI) }\end{array}$ & Comments \\
\hline & $\begin{array}{l}\text { Prothioconazole } \\
\text { (Proline }^{\circledR} 480 \text { SC) }\end{array}$ & $5.7 \mathrm{fl} \mathrm{oz}$ & ++++ & $12 \mathrm{~h}$ & 7 days & $\begin{array}{l}\text { Make up to } 2 \text { applications per year } \\
\text { on a 7-10 day schedule. }\end{array}$ \\
\hline & $\begin{array}{l}\text { Chlorothalonil } \\
\text { (Bravo Weather } \\
\text { Stik }^{\circledast} \text { ) }\end{array}$ & $3-4 \mathrm{pt}$ & ++++ & $\begin{array}{l}12 \mathrm{~h} \text { (with } \\
\text { restrictions) } 6.5 \\
\text { days (w/o) }\end{array}$ & 42 days & $\begin{array}{l}\text { Apply only as a postharvest } \\
\text { fungicide for Septoria and rust. Do } \\
\text { not combine with other pesticides, } \\
\text { surfactants, or fertilizers. }\end{array}$ \\
\hline & $\begin{array}{l}\text { Cyprodinil + } \\
\text { fludioxonil } \\
\text { (Switch }{ }^{\circledast} 62.5 W G \text { ) }\end{array}$ & $11-14 \mathrm{oz}$ & +++ & $12 \mathrm{~h}$ & 0 days & $\begin{array}{l}\text { Applications can be made at 7-to- } \\
\text { 10-day intervals when conditions } \\
\text { warrant. Do not apply more than } \\
56 \text { oz of product per acre per year. } \\
\text { Make no more than two sequential } \\
\text { applications before using another } \\
\text { fungicide with a different mode of } \\
\text { action. }\end{array}$ \\
\hline & $\begin{array}{l}\text { Fluopyram + } \\
\text { pyrimethanil } \\
(\text { Luna } \\
\text { Tranquility }^{\oplus} \text { ) }\end{array}$ & $16-27 \mathrm{fl} \mathrm{oz}$ & $?$ & $12 \mathrm{~h}$ & 0 days & $\begin{array}{l}\text { Do not apply more than } 54.7 \mathrm{fl} \\
\text { oz per acre per year. Rotate to a } \\
\text { different fungicide group after } \\
\text { no more than } 2 \text { applications. } \\
\text { Reapplication interval is } 7 \text { to } 14 \\
\text { days. No efficacy data for this } \\
\text { product are available for blueberry } \\
\text { in Florida. Only Luna Tranquility is } \\
\text { labeled for blueberry in Florida. }\end{array}$ \\
\hline Bacterial wilt & $\begin{array}{l}\text { Phosphorous acid } \\
\text { soil application } \\
\text { (K-Phite) }\end{array}$ & $2-4 \mathrm{qt}$ & +++ & $4 \mathrm{~h}$ & 0 days & $\begin{array}{l}\text { For bacterial wilt, the product } \\
\text { must be soil-applied. Follow label } \\
\text { instructions for chemigation or } \\
\text { directed soil application with light } \\
\text { irrigation. Reapplication interval } \\
\text { is } 3 \text { to } 28 \text { days. Make applications } \\
\text { postharvest through end of } \\
\text { summer. }\end{array}$ \\
\hline \multirow[t]{2}{*}{$\begin{array}{l}\text { Botrytis } \\
\text { flower blight }\end{array}$} & $\begin{array}{l}\text { Cyprodinil + } \\
\text { fludioxonil } \\
\text { (Switch }{ }^{\circledast} 62.5 \mathrm{WG} \text { ) }\end{array}$ & $11-14$ oz & +++++ & $12 \mathrm{~h}$ & 0 days & $\begin{array}{l}\text { Make the first application } \\
\text { during early bloom. Subsequent } \\
\text { applications should be made every } \\
7-10 \text { days during bloom. Do not } \\
\text { apply more than } 56 \text { oz of product } \\
\text { per acre per year. Make no more } \\
\text { than two sequential applications } \\
\text { before using another fungicide } \\
\text { with a different mode of action. }\end{array}$ \\
\hline & $\begin{array}{l}\text { Fenhexamid } \\
\text { (Elevate }^{\circledR} 50 \\
\text { WDG) }\end{array}$ & $1.5 \mathrm{lb}$ & +++++ & $12 \mathrm{~h}$ & 0 days & $\begin{array}{l}\text { Begin application at } 10 \% \text { bloom. } \\
\text { Applications should be made } \\
\text { every } 7 \text { days when conditions } \\
\text { favor disease. Resistance is known } \\
\text { to occur; do not make more than } \\
\text { two consecutive applications } \\
\text { without switching to a fungicide } \\
\text { with a different mode of action. } \\
\text { Do not apply more than } 6.0 \mathrm{lb} \text { of } \\
\text { product per acre per year. }\end{array}$ \\
\hline
\end{tabular}




\begin{tabular}{|c|c|c|c|c|c|c|}
\hline Disease & $\begin{array}{l}\text { Management } \\
\text { Options }\end{array}$ & $\begin{array}{c}\text { Amount of } \\
\text { Formulation } \\
\text { per Acre }\end{array}$ & $\begin{array}{c}\text { Effectiveness } \\
\text { (Least }=+ \text { to } \\
\text { Most }=+++++)\end{array}$ & $\begin{array}{c}\text { Restricted } \\
\text { Entry Interval } \\
\text { (REI) }\end{array}$ & $\begin{array}{l}\text { Postharvest } \\
\text { Interval (PHI) }\end{array}$ & Comments \\
\hline & $\begin{array}{l}\text { Pyraclostrobin } \\
+ \text { boscalid } \\
\left(\text { Pristine }^{\circledast}\right)\end{array}$ & $18.5-23 \mathrm{oz}$ & +++++ & $12 \mathrm{~h}$ & 0 days & $\begin{array}{l}\text { Resistance is known to occur; } \\
\text { no more than two sequential } \\
\text { applications of Pristine }{ }^{\circledast} \text { should } \\
\text { be made before alternating with } \\
\text { fungicides that have a different } \\
\text { mode of action. Do not apply more } \\
\text { than four applications of Pristine }{ }^{\circledast} \\
\text { per acre per crop year. Do not mix } \\
\text { Pristine }{ }^{\circledast} \text { with anything other than } \\
\text { Captan. }\end{array}$ \\
\hline & $\begin{array}{l}\text { Fluopyram + } \\
\text { pyrimethanil } \\
\text { (Luna } \\
\text { Tranquility }^{\circledast} \text { ) }\end{array}$ & 13.6-27 fl oz & $?$ & $12 \mathrm{~h}$ & 0 days & $\begin{array}{l}\text { Do not apply more than } 54.7 \mathrm{fl} \\
\text { oz per acre per year. Rotate to a } \\
\text { different fungicide group after } \\
\text { no more than } 2 \text { applications. } \\
\text { Reapplication interval is } 7 \text { to } 14 \\
\text { days. }\end{array}$ \\
\hline & $\begin{array}{l}\text { Ziram (Ziram } \\
\text { 76DF) }\end{array}$ & $3 \mathrm{lb}$ & ++ & $48 \mathrm{~h}$ & 30 days & $\begin{array}{l}\text { Do not apply later than } 3 \text { weeks } \\
\text { after full bloom. }\end{array}$ \\
\hline & $\begin{array}{l}\text { Captan (Captan } \\
\text { 50WP) }\end{array}$ & $5 \mathrm{lb}$ & ++ & $48 \mathrm{~h}$ & 0 days & $\begin{array}{l}\text { Do not apply more than } 70 \mathrm{lb} \text { per } \\
\text { acre per crop year. }\end{array}$ \\
\hline & $\begin{array}{l}\text { Captan (Captan } \\
\left.4 \mathrm{~L}^{\circledR}\right)\end{array}$ & $2 \mathrm{qt}$ & ++ & $48 \mathrm{~h}$ & 0 days & $\begin{array}{l}\text { Do not apply more than } 35 \text { qt per } \\
\text { acre per crop year. }\end{array}$ \\
\hline $\begin{array}{l}\text { Dieback } \\
\text { diseases } \\
\text { (post- } \\
\text { hedging) }\end{array}$ & $\begin{array}{l}\text { Captan } \\
\text { mixed with a } \\
\text { phosphorous acid } \\
\text { product (Captan } \\
\text { 50WP + Prophyt }{ }^{\circledR}\end{array}$ & $5 \mathrm{lb}+4 \mathrm{pt}$ & +++ & $48 \mathrm{~h}$ & 0 days & $\begin{array}{l}\text { Apply immediately after } \\
\text { postharvest hedging. }\end{array}$ \\
\hline $\begin{array}{l}\text { Phytophthora } \\
\text { root rot }\end{array}$ & $\begin{array}{l}\text { Fosetyl-Al } \\
\text { (Aliette }{ }^{\circledast} \text { WDG) }\end{array}$ & $5 \mathrm{lb}$ & +++ & $12 \mathrm{~h}$ & $12 \mathrm{~h}$ & $\begin{array}{l}\text { Apply Aliette }{ }^{\circledR} \text { as a foliar spray } \\
\text { for Phytophthora and Pythium } \\
\text { root rots and Septoria leaf } \\
\text { spot. Subsequent applications } \\
\text { can be made at } 14 \text {-to-21-day } \\
\text { intervals. Two or three fungicide } \\
\text { applications following harvest } \\
\text { are generally sufficient to prevent } \\
\text { major outbreaks of Septoria leaf } \\
\text { spot. Assuming that hedging is } \\
\text { conducted immediately following } \\
\text { harvest, this is a good time to } \\
\text { consider an application. Do not } \\
\text { exceed four applications per acre } \\
\text { per year. } \\
\text { Do not tank mix with copper } \\
\text { and foliar fertilizers and do not } \\
\text { apply in acidic water or add } \\
\text { acidifying agents, because these } \\
\text { practices could damage fruit or } \\
\text { foliage. When tank-mixing this } \\
\text { product with others, test the mix } \\
\text { on a small area to make sure that } \\
\text { phytotoxicity does not occur. }\end{array}$ \\
\hline
\end{tabular}




\begin{tabular}{|c|c|c|c|c|c|c|}
\hline Disease & $\begin{array}{l}\text { Management } \\
\text { Options }\end{array}$ & $\begin{array}{l}\text { Amount of } \\
\text { Formulation } \\
\text { per Acre }\end{array}$ & $\begin{array}{c}\text { Effectiveness } \\
\text { (Least }=+ \text { to } \\
\text { Most }=+++++)\end{array}$ & $\begin{array}{c}\text { Restricted } \\
\text { Entry Interval } \\
\text { (REI) }\end{array}$ & $\begin{array}{l}\text { Postharvest } \\
\text { Interval (PHI) }\end{array}$ & Comments \\
\hline & $\begin{array}{l}\text { Mefenoxam } \\
\text { (Ridomil Gold }^{\circledast} \\
\text { SL) }\end{array}$ & $3.6 \mathrm{pt}$ & ++++ & $48 \mathrm{~h}$ & 0 days & $\begin{array}{l}\text { Established plantings: Apply } \\
1 / 4 \text { pt/1000 linear feet of row ( } 3.6 \\
\text { pt per acre broadcast basis) in a } \\
\text { 3-foot band over the row. One } \\
\text { application prior to bloom and one } \\
\text { additional application postharvest, } \\
\text { approximately } 6 \text { months later. } \\
\text { New plantings: Apply } 3.6 \text { pt } \\
\text { per acre (broadcast rate) at or } \\
\text { after planting. An } 18 \text {-inch band } \\
\text { over the row is recommended. } \\
\text { Do not apply more than } 0.9 \\
\text { gal per acre broadcast during } \\
\text { the } 12 \text { months before plants } \\
\text { bear harvestable fruit, or illegal } \\
\text { residues may result. For both new } \\
\text { and established plantings, one } \\
\text { additional application may be } \\
\text { made to coincide with periods } \\
\text { most favorable for root rot } \\
\text { development. }\end{array}$ \\
\hline & $\begin{array}{l}\text { Potassium } \\
\text { phosphite } \\
\left(\text { Prophyt }^{\oplus}\right)\end{array}$ & $4 \mathrm{pt}$ & ++++ & $4 \mathrm{~h}$ & 0 days & $\begin{array}{l}\text { Apply as a foliar spray for } \\
\text { Phytophthora and Pythium. } \\
\text { Also effective against Septoria } \\
\text { and anthracnose leaf spots. Do } \\
\text { not tank mix with copper and } \\
\text { foliar fertilizers and do not } \\
\text { apply in acidic water or add } \\
\text { acidifying agents, because these } \\
\text { practices could damage fruit or } \\
\text { foliage. When tank-mixing this } \\
\text { product with others, test the mix } \\
\text { on a small area to make sure that } \\
\text { phytotoxicity does not occur. }\end{array}$ \\
\hline & $\begin{array}{l}\text { Oxythiopiprolin } \\
\text { (Orondis }{ }^{\circledR} \text { Gold } \\
200 \text { ) }\end{array}$ & 4.8 to $9.6 \mathrm{fl} \mathrm{oz}$ & $?$ & $4 \mathrm{~h}$ & 1 day & $\begin{array}{l}\text { Apply as a soil drench, as a } \\
\text { soil-directed spray, or through } \\
\text { irrigation system in spring before } \\
\text { plants begin to grow, with a } \\
\text { follow-up application postharvest } \\
\text { prior to the rainy season. }\end{array}$ \\
\hline & $\begin{array}{l}\text { Oxythiopiprolin, } \\
\text { Mefenoxam } \\
\text { (Orondis }{ }^{\circledR} \text { Gold) }\end{array}$ & 28 to $55 \mathrm{fl} \mathrm{oz}$ & $?$ & $48 \mathrm{~h}$ & 1 day & $\begin{array}{l}\text { Apply as a soil drench, as a } \\
\text { soil-directed spray, or through } \\
\text { irrigation system in spring before } \\
\text { plants begin to grow, with a } \\
\text { follow-up application postharvest } \\
\text { prior to the rainy season. }\end{array}$ \\
\hline
\end{tabular}


Table 2. Insect and Mite Pest Management Options.

\begin{tabular}{|c|c|c|c|c|c|c|}
\hline Pest & $\begin{array}{l}\text { Management } \\
\text { Options }\end{array}$ & $\begin{array}{l}\text { Amount of } \\
\text { Formulation } \\
\text { per Acre }\end{array}$ & $\begin{array}{c}\text { Effectiveness } \\
\text { (Least }=+ \text { to } \\
\text { Most }=+++++)\end{array}$ & $\begin{array}{l}\text { Restricted } \\
\text { Entry Interval } \\
\quad \text { (REI) }\end{array}$ & $\begin{array}{l}\text { Postharvest } \\
\text { Interval } \\
\text { (PHI) }\end{array}$ & Comments \\
\hline \multirow[t]{4}{*}{ Azalea caterpillar } & $\begin{array}{l}\text { Bacillus } \\
\text { thuringiensis [BT] } \\
\text { (DiPel }{ }^{\circledR} \text { DF) }\end{array}$ & $0.5-1.0 \mathrm{lb}$ & ++ & $4 \mathrm{~h}$ & 0 days & $\begin{array}{l}\text { DiPel }^{\circledR} \text { is an effective microbial } \\
\text { insecticide. However, it should } \\
\text { be applied to small, early-stage } \\
\text { caterpillars. }\end{array}$ \\
\hline & $\begin{array}{l}\text { Tebufenozide } \\
\left.\text { (Confirm }{ }^{\circledast} 2 \mathrm{~F}\right)\end{array}$ & 4-8 fl oz & ++++ & $4 \mathrm{~h}$ & 14 days & $\begin{array}{l}\text { Confirm }{ }^{\circledast} \text { is very effective if } \\
\text { applied to small, early-stage } \\
\text { caterpillars. }\end{array}$ \\
\hline & $\begin{array}{l}\text { Esfenvalerate } \\
\text { (Asana }^{\circledast} 0.66 \mathrm{EC} \text { ) }\end{array}$ & $4.8-16 \mathrm{oz}$ & ++++ & $12 \mathrm{~h}$ & 14 days & $\begin{array}{l}\text { Esfenvalerate should be used } \\
\text { as a salvage treatment for large } \\
\text { caterpillars. It is very effective, } \\
\text { but if used often it encourages } \\
\text { scale and mite buildup. }\end{array}$ \\
\hline & $\begin{array}{l}\text { Esfenvalerate } \\
\text { (Adjourn }^{\circledast} 0.66 \mathrm{EC} \text { ) }\end{array}$ & $4.8-9.6 \mathrm{fl} \mathrm{oz}$ & ++++ & $12 \mathrm{~h}$ & 14 days & $\begin{array}{l}\text { Some users may be allergic to } \\
\text { Adjourn }{ }^{\oplus} \text {; discontinue use if skin } \\
\text { or eyes become inflamed. }\end{array}$ \\
\hline \multirow[t]{4}{*}{$\begin{array}{l}\text { Blueberry bud } \\
\text { mite }\end{array}$} & $\begin{array}{l}\text { Fenazaquin } \\
\text { (Magister }^{\circledast} \text { SC) }\end{array}$ & $24-36 \mathrm{fl} \mathrm{oz}$ & +++ & $12 \mathrm{~h}$ & 7 days & $\begin{array}{l}\text { Apply in at least } 50 \text { gallons of } \\
\text { water per acre. Use higher rates } \\
\text { for heavier mite pressure. Do not } \\
\text { make more than one application } \\
\text { per year. }\end{array}$ \\
\hline & $\begin{array}{l}\text { Fenpyroximate } \\
\left(\text { Portal }^{\circledR}\right)\end{array}$ & $2 \mathrm{pt}$ & +++ & $12 \mathrm{~h}$ & 1 day & $\begin{array}{l}\text { Growers can make two } \\
\text { applications per year. }\end{array}$ \\
\hline & $\begin{array}{l}\text { Horticultural oil } \\
\text { (JMS Stylet-Oil }^{\circledR} \text { ) }\end{array}$ & $3-6 \mathrm{qt} / 100 \mathrm{gal}$ & ++ & $4 \mathrm{~h}$ & 0 days & $\begin{array}{l}\text { Blueberry bud mite cannot be } \\
\text { readily seen, and by the time } \\
\text { symptoms are observed in } \\
\text { the spring, the mites are too } \\
\text { deep for effective treatment. } \\
\text { Avoid using this product if the } \\
\text { temperature is above } 85^{\circ} \mathrm{F} \text {. }\end{array}$ \\
\hline & $\begin{array}{l}\text { Horticultural oil } \\
\text { (Stoller Golden } \\
\text { Pest Spray Oil) }\end{array}$ & $\begin{array}{l}2 \text { gal (low } \\
\text { volume) } \\
\text { application or } \\
2 \text { gal/100 gal } \\
\text { (dilute spray) }\end{array}$ & ++ & $4 \mathrm{~h}$ & 0 days & $\begin{array}{l}\text { Avoid using this product if the } \\
\text { temperature is above } 85^{\circ} \mathrm{F} \text {. }\end{array}$ \\
\hline \multirow[t]{5}{*}{$\begin{array}{l}\text { Blueberry gall } \\
\text { midge }\end{array}$} & $\begin{array}{l}\text { Spirotetramat } \\
\text { (Movento }^{\circledast} \text { ) }\end{array}$ & $5-6 \mathrm{fl} \mathrm{oz}$ & ++++ & $12 \mathrm{~h}$ & 7 days & $\begin{array}{l}\text { Do not apply more than } 25 \mathrm{fl} \mathrm{oz} \\
\text { per acre per season. }\end{array}$ \\
\hline & $\begin{array}{l}\text { Spinetoram } \\
\text { (Delegate }{ }^{\circledR} \text { WG) }\end{array}$ & $3-6$ oz & +++ & $4 \mathrm{~h}$ & 3 days & $\begin{array}{l}\text { Do not apply more than } 19.5 \\
\text { oz of Delegate or } 0.3 \mathrm{lb} \text { a.i. } \\
\text { spinetoram per acre per season. } \\
\text { Delegate }{ }^{\circledR} \text { WG is toxic to bees } \\
\text { until } 3 \mathrm{~h} \text { after application when } \\
\text { it is thoroughly dry. }\end{array}$ \\
\hline & $\begin{array}{l}\text { Acetamiprid } \\
\text { (Assail }^{\otimes} \text { 30SG) }\end{array}$ & $4.5-5.3 \mathrm{oz}$ & +++ & $12 \mathrm{~h}$ & 1 day & $\begin{array}{l}\text { Do not apply within } 4 \text { days of } \\
\text { bloom. }\end{array}$ \\
\hline & $\begin{array}{l}\text { Cyantraniliprole } \\
\left(\text { Exirel }^{\circledast}\right)\end{array}$ & $13.5-20.5 \mathrm{fl} \mathrm{oz}$ & +++ & $12 \mathrm{~h}$ & 3 days & $\begin{array}{l}\text { Do not apply within } 4 \text { days of } \\
\text { bloom. Minimum application } \\
\text { interval between treatments is } \\
5 \text { days. }\end{array}$ \\
\hline & $\begin{array}{l}\text { Spinosad } \\
\left.\text { (Entrust }^{\oplus}\right) \\
\text { Labeled for } \\
\text { organic use }\end{array}$ & $1.25-2 \mathrm{oz}$ & +++ & $4 \mathrm{~h}$ & 3 days & $\begin{array}{l}\text { Entrust }^{\circledast} \text { is toxic to bees until it } \\
\text { is thoroughly dry ( } 3 \text { hours), but } \\
\text { thereafter it is relatively nontoxic } \\
\text { to bees. Entrust }{ }^{\circledR} \text { should be } \\
\text { applied in early morning or late } \\
\text { evening during bloom. }\end{array}$ \\
\hline
\end{tabular}




\begin{tabular}{|c|c|c|c|c|c|c|}
\hline Pest & $\begin{array}{l}\text { Management } \\
\text { Options }\end{array}$ & $\begin{array}{l}\text { Amount of } \\
\text { Formulation } \\
\text { per Acre }\end{array}$ & $\begin{array}{c}\text { Effectiveness } \\
\text { (Least }=+ \text { to } \\
\text { Most }=+++++)\end{array}$ & $\begin{array}{l}\text { Restricted } \\
\text { Entry Interval } \\
\quad \text { (REI) }\end{array}$ & $\begin{array}{l}\text { Postharvest } \\
\text { Interval } \\
\text { (PHI) }\end{array}$ & Comments \\
\hline & $\begin{array}{l}\text { Malathion } \\
\text { (Malathion } 57 \mathrm{EC} \text { ) }\end{array}$ & $2 \mathrm{pt}$ & +++ & $12 \mathrm{~h}$ & 1 day & $\begin{array}{l}\text { Malathion has low toxicity to } \\
\text { bees and beneficial insects. }\end{array}$ \\
\hline & $\begin{array}{l}\text { Diazinon } \\
\text { (Diazinon AG 500) }\end{array}$ & $1 \mathrm{pt}$ & +++ & 5 days & 7 days & $\begin{array}{l}\text { Do not apply within } 4 \text { days of } \\
\text { bloom. }\end{array}$ \\
\hline & $\begin{array}{l}\text { Tolfenpyrad } \\
\left(\text { Apta }^{\circledR}\right)\end{array}$ & $27 \mathrm{fl} \mathrm{oz/acre}$ & ++ & $12 \mathrm{~h}$ & 3 days & $\begin{array}{l}\text { Allow } 14 \text { days between } \\
\text { applications. }\end{array}$ \\
\hline \multirow[t]{7}{*}{$\begin{array}{l}\text { Blueberry } \\
\text { maggot }\end{array}$} & $\begin{array}{l}\text { Phosmet (Imidan }{ }^{\circledast} \\
\text { 70W) }\end{array}$ & $1.3 \mathrm{lb}$ & ++++ & $24 \mathrm{~h}$ & 3 days & $\begin{array}{l}\text { Imidan }{ }^{\circledast} \text { is the material of choice } \\
\text { for managing BBM. BBM sprays } \\
\text { should protect berries from the } \\
\text { start of oviposition until the last } \\
\text { berries are harvested. Imidan }{ }^{\circledast} \\
\text { provides } 10-14 \text { days residual } \\
\text { control. Do not apply more than } \\
\text { twice per season. }\end{array}$ \\
\hline & $\begin{array}{l}\text { Carbaryl (Sevin }{ }^{\circledast} \\
\text { 4F) }\end{array}$ & $1.9-2.5 \mathrm{lb}$ & +++ & $12 \mathrm{~h}$ & 7 days & $\begin{array}{l}\text { BBM sprays should protect } \\
\text { berries from the start of } \\
\text { oviposition until the last } \\
\text { berries are harvested. Sevin }{ }^{\circledast} \\
\text { provides 5-7 days of residual } \\
\text { effectiveness. }\end{array}$ \\
\hline & $\begin{array}{l}\text { Malathion } \\
\text { (Malathion } 57 \mathrm{EC} \text { ) }\end{array}$ & $1.5 \mathrm{pt}$ & +++ & $12 \mathrm{~h}$ & 1 day & $\begin{array}{l}\text { BBM sprays should protect } \\
\text { berries from the start of } \\
\text { oviposition until the last berries } \\
\text { are harvested. Malathion } \\
\text { provides 5-7 days of residual } \\
\text { control. }\end{array}$ \\
\hline & $\begin{array}{l}\text { Diazinon } \\
\text { (Diazinon AG500) }\end{array}$ & $1 \mathrm{pt} / 100 \mathrm{gal}$ & ++++ & $24 \mathrm{~h}$ & 7 days & $\begin{array}{l}\text { Allow } 14 \text { days between } \\
\text { applications. }\end{array}$ \\
\hline & $\begin{array}{l}\text { Spinetoram } \\
\text { (Delegate }^{\circledast} \text { WG) }\end{array}$ & $3-6 o z$ & +++ & $4 \mathrm{~h}$ & 3 days & $\begin{array}{l}\text { Do not apply more than } 17.9 \\
\text { oz of Delegate or } 0.28 \mathrm{lb} \text { a.i. } \\
\text { spinetoram per acre per season. }\end{array}$ \\
\hline & $\begin{array}{l}\text { Tolfenpyrad } \\
\left(\text { Apta }^{\circledR}\right)\end{array}$ & $27 \mathrm{fl} \mathrm{oz/acre}$ & ++ & $12 \mathrm{~h}$ & 3 days & $\begin{array}{l}\text { Allow } 14 \text { days between } \\
\text { applications. }\end{array}$ \\
\hline & $\begin{array}{l}\text { Spirotetramat } \\
\text { (Movento }^{\circledast} \text { ) }\end{array}$ & 8-10 fl oz/acre & +++ & $24 \mathrm{~h}$ & 7 days & $\begin{array}{l}\text { Minimum interval of } 7 \text { days } \\
\text { between applications. }\end{array}$ \\
\hline \multirow[t]{5}{*}{ Chilli thrips } & $\begin{array}{l}\text { Spinetoram } \\
\text { (Delegate }{ }^{\circledR} \text { WG) }\end{array}$ & $6 \mathrm{oz}$ & +++ & $4 \mathrm{~h}$ & 3 days & $\begin{array}{l}\text { Delegate }{ }^{\circledast} \text { WG may be applied } \\
\text { as needed. Delegate }{ }^{\circledR} \text { WG } \\
\text { should be applied in the early } \\
\text { morning. It is toxic to bees in the } \\
\text { surrounding areas for the first } 3 \\
\text { hours after application. }\end{array}$ \\
\hline & $\begin{array}{l}\text { Acetamiprid } \\
\text { (Assail }^{\otimes} \text { 30SG) }\end{array}$ & $2.4 \mathrm{oz}$ & +++ & $12 \mathrm{~h}$ & 1 day & $\begin{array}{l}\text { Do not make more than four } \\
\text { applications per season. Toxic } \\
\text { to bees until spray is dry } \\
\text { (approximately } 3 \text { hours). }\end{array}$ \\
\hline & $\begin{array}{l}\text { Malathion } \\
\text { (Malathion } 57 \mathrm{EC} \text { ) }\end{array}$ & $2 \mathrm{pt}$ & ++ & $12 \mathrm{~h}$ & 1 day & $\begin{array}{l}\text { Malathion should be applied } \\
\text { in the early morning or late } \\
\text { evening to reduce the disruption } \\
\text { of beneficial insects. }\end{array}$ \\
\hline & $\begin{array}{l}\text { Spinosad } \\
\left.\text { (Entrust }^{\oplus}\right) \\
\text { (labeled for } \\
\text { organic use) }\end{array}$ & $1.25-2 \mathrm{oz}$ & +++ & $4 \mathrm{~h}$ & 3 days & $\begin{array}{l}\text { It is toxic to bees in the } \\
\text { surrounding areas for the first } 3 \\
\text { hours after application. }\end{array}$ \\
\hline & $\begin{array}{l}\text { Flupyradifurone } \\
\text { (Sivanto }^{\circledast} 200 \mathrm{SL} \text { ) }\end{array}$ & 2-4 fl oz/acre & +++ & $4 \mathrm{~h}$ & 3 days & $\begin{array}{l}\text { You should allow a minimum of } \\
7 \text { days between applications. }\end{array}$ \\
\hline
\end{tabular}




\begin{tabular}{|c|c|c|c|c|c|c|}
\hline Pest & $\begin{array}{l}\text { Management } \\
\text { Options }\end{array}$ & $\begin{array}{l}\text { Amount of } \\
\text { Formulation } \\
\text { per Acre }\end{array}$ & $\begin{array}{l}\text { Effectiveness } \\
(\text { Least }=+ \text { to } \\
\text { Most }=+++++)\end{array}$ & $\begin{array}{l}\text { Restricted } \\
\text { Entry Interval } \\
\text { (REI) }\end{array}$ & $\begin{array}{l}\text { Postharvest } \\
\text { Interval } \\
\text { (PHI) }\end{array}$ & Comments \\
\hline & $\begin{array}{l}\text { Tolfenpyrad } \\
\left(\text { Apta }{ }^{\circledR}\right)\end{array}$ & $27.0 \mathrm{fl} \mathrm{oz/acre}$ & ++++ & $12 \mathrm{~h}$ & 3 days & $\begin{array}{l}\text { Apply by ground only. Maximum } \\
\text { of } 3 \text { applications per season or } \\
81 \mathrm{fl} \mathrm{oz/acre/season.}\end{array}$ \\
\hline & $\begin{array}{l}\text { Novaluron } \\
\text { (Rimon }^{\circledR} 0.83 \mathrm{EC} \text { ) }\end{array}$ & $\begin{array}{l}20-30 \mathrm{floz} / \\
\text { acre }\end{array}$ & ++ & $12 \mathrm{~h}$ & 8 days & \\
\hline \multirow[t]{7}{*}{$\begin{array}{l}\text { Cranberry } \\
\text { fruitworm }\end{array}$} & $\begin{array}{l}\text { Malathion } \\
\text { (Malathion } 57 \mathrm{EC} \text { ) }\end{array}$ & $2.8-3.2 \mathrm{pt}$ & +++ & $12 \mathrm{~h}$ & 1 day & $\begin{array}{l}\text { Spray fruitworms when one } \\
\text { bush in five has infested fruit } \\
\text { clusters. }\end{array}$ \\
\hline & $\begin{array}{l}\text { Esfenvalerate } \\
\text { (Asana }{ }^{\circledR} \text { XL } 0.66 \\
\text { EC) }\end{array}$ & $4.8-9.6 \mathrm{fl} \mathrm{oz}$ & ++++ & $12 \mathrm{~h}$ & 14 days & $\begin{array}{l}\text { Some users may be allergic to } \\
\text { Asana }{ }^{\circledR} \text {; discontinue use if skin or } \\
\text { eyes become inflamed. }\end{array}$ \\
\hline & $\begin{array}{l}\text { Esfenvalerate } \\
\text { (Adjourn }{ }^{\circledast} 0.66 \mathrm{EC} \text { ) }\end{array}$ & $4.8-9.6 \mathrm{fl} \mathrm{oz}$ & ++++ & $12 \mathrm{~h}$ & 14 days & $\begin{array}{l}\text { Some users may be allergic to } \\
\text { Adjourn }^{\circledR} \text {; discontinue use if skin } \\
\text { or eyes become inflamed. }\end{array}$ \\
\hline & $\begin{array}{l}\text { Phosmet (Imidan }{ }^{\circledast} \\
70-W)\end{array}$ & $1.3 \mathrm{lb}$ & $\begin{array}{c}+++++ \\
\text { (for fruitworms) } \\
+++++ \\
\text { (for plum } \\
\text { curculio) }\end{array}$ & $24 \mathrm{~h}$ & 3 days & $\begin{array}{l}\text { Imidan }{ }^{\circledast} \text { produces } 7-10 \text { days of } \\
\text { residual control. Begin spraying } \\
\text { after petal fall. }\end{array}$ \\
\hline & $\begin{array}{l}\text { Carbaryl (Sevin }{ }^{\circledR} \\
\text { 4F) }\end{array}$ & $1.9-2.5 \mathrm{lb}$ & $\begin{array}{c}+++ \\
\text { (for fruitworms) }\end{array}$ & $12 \mathrm{~h}$ & 7 days & $\begin{array}{l}\text { Sevin }^{\circledast} \text { gives only moderate } \\
\text { control of fruitworms. }\end{array}$ \\
\hline & $\begin{array}{l}\text { Tebufenozide } \\
\text { (Confirm }{ }^{\circledast} 2 \mathrm{~F} \text { ) }\end{array}$ & $16 \mathrm{fl} \mathrm{oz}$ & $\begin{array}{c}+++++ \\
\text { (for fruitworms) }\end{array}$ & $4 \mathrm{~h}$ & 14 days & $\begin{array}{l}\text { Confirm }^{\circledast} \text { gives very good } \\
\text { control for cranberry fruitworms. } \\
\text { Confirm needs to be ingested } \\
\text { to be effective; therefore, timing } \\
\text { is critical. Apply Confirm }{ }^{\circledast} \\
\text { while fruitworms are still small. } \\
\text { Confirm }{ }^{\circledast} \text { conserves natural } \\
\text { enemies. }\end{array}$ \\
\hline & $\begin{array}{l}\text { Tolfenpyrad } \\
\left(\text { Apta }^{\circledR}\right)\end{array}$ & $27 \mathrm{fl} \mathrm{oz/acre}$ & ++ & $12 \mathrm{~h}$ & 3 days & $\begin{array}{l}\text { Allow } 14 \text { days between } \\
\text { applications. }\end{array}$ \\
\hline \multirow[t]{5}{*}{$\begin{array}{l}\text { Diaprepes (Citrus } \\
\text { root weevil) }\end{array}$} & $\begin{array}{l}\text { Bifenthrin } \\
\text { (Brigade }^{\circledast} 2 \mathrm{EC} \text { ) }\end{array}$ & 10-16 oz/acre & +++ & $12 \mathrm{~h}$ & 1 day & Foliar spray for control of adults. \\
\hline & $\begin{array}{l}\text { Fenpropathrin } \\
\left.\text { (Danitol }^{\circledR} 2.4 \mathrm{EC}\right)\end{array}$ & 8-10 fl oz/acre & +++ & $24 \mathrm{~h}$ & 3 days & Foliar spray for control of adults. \\
\hline & $\begin{array}{l}\text { Thiamethoxam } \\
\left(\text { Actara }^{\oplus)}\right.\end{array}$ & $3-4$ oz & +++ & $12 \mathrm{~h}$ & 3 days & $\begin{array}{l}\text { Foliar spray for control of adults. } \\
\text { Actara }{ }^{\circledR} \text { and Platinum }{ }^{\circledast} \text { are } \\
\text { neonicotinoids and should not } \\
\text { follow each other in a rotation } \\
\text { program. }\end{array}$ \\
\hline & $\begin{array}{l}\text { Thiamethoxam } \\
\text { (Platinum }^{\circledast} \text { ) }\end{array}$ & $5-12 \mathrm{fl} \mathrm{oz}$ & +++ & $12 \mathrm{~h}$ & 75 days & $\begin{array}{l}\text { For larval control by directly } \\
\text { drenching the soil area beneath } \\
\text { the plant canopy or by applying } \\
\text { through drip or microjet } \\
\text { irrigation systems. Actara }^{\circledR} \text { and } \\
\text { Platinum }{ }^{\circledR} \text { are neonicotinoids } \\
\text { and should not follow each } \\
\text { other in a rotation program. }\end{array}$ \\
\hline & $\begin{array}{l}\text { Bifenthrin } \\
\text { (Brigade }^{\circledast} 2 \mathrm{EC} \text { ) }\end{array}$ & $10-16$ oz & ++++ & $12 \mathrm{~h}$ & $\begin{array}{l}\text { Do not as a } \\
\text { soil drench } \\
\text { during } \\
\text { harvest. }\end{array}$ & $\begin{array}{l}\text { For larval control by directly } \\
\text { drenching the soil area beneath } \\
\text { the plant canopy or by applying } \\
\text { through drip or microjet } \\
\text { irrigation systems. Do not use as } \\
\text { a soil drench during harvest. }\end{array}$ \\
\hline
\end{tabular}




\begin{tabular}{|c|c|c|c|c|c|c|}
\hline Pest & $\begin{array}{l}\text { Management } \\
\text { Options }\end{array}$ & $\begin{array}{l}\text { Amount of } \\
\text { Formulation } \\
\text { per Acre }\end{array}$ & $\begin{array}{c}\text { Effectiveness } \\
\text { (Least }=+ \text { to } \\
\text { Most }=+++++)\end{array}$ & $\begin{array}{l}\text { Restricted } \\
\text { Entry Interval } \\
\quad \text { (REI) }\end{array}$ & $\begin{array}{l}\text { Postharvest } \\
\text { Interval } \\
\text { (PHI) }\end{array}$ & Comments \\
\hline & $\begin{array}{l}\text { Fenpropathrin } \\
\left.\text { (Danitol }^{\circledast} 2.4 \mathrm{EC}\right)\end{array}$ & $10-16$ oz & +++ & $24 \mathrm{~h}$ & 3 days & $\begin{array}{l}\text { For larval control by directly } \\
\text { drenching the soil area beneath } \\
\text { the plant canopy or by applying } \\
\text { through drip or microjet } \\
\text { irrigation systems. }\end{array}$ \\
\hline & $\begin{array}{l}\text { Imidacloprid } \\
\text { (Admire }{ }^{\circledR} \text { Pro) }\end{array}$ & $2.1-2.8 \mathrm{oz}$ & +++ & $12 \mathrm{~h}$ & 3 days & $\begin{array}{l}\text { Should not follow rotation } \\
\text { with Platinum }{ }^{\circledast} \text {. They are both } \\
\text { neonicotinoids. }\end{array}$ \\
\hline Flatheaded borer & $\begin{array}{l}\text { Thiamethoxam } \\
\text { (Platinum }^{\circledR} \text { ) }\end{array}$ & $5-12$ fl oz & +++ & $12 \mathrm{~h}$ & 75 days & $\begin{array}{l}\text { For larval control by directly } \\
\text { drenching the soil area beneath } \\
\text { the plant canopy or by applying } \\
\text { through drip or microjet } \\
\text { irrigation systems. }\end{array}$ \\
\hline \multirow[t]{4}{*}{ Flea beetles } & $\begin{array}{l}\text { Carbaryl (Sevin }{ }^{\circledR} \\
\text { 4F) }\end{array}$ & $1-2 \mathrm{lb}$ & +++ & $12 \mathrm{~h}$ & 7 days & $\begin{array}{l}\text { Sevin }^{\oplus} \text { is also effective against } \\
\text { small to medium-sized } \\
\text { caterpillars. }\end{array}$ \\
\hline & $\begin{array}{l}\text { Diazinon } \\
\text { (Diazinon AG500) }\end{array}$ & $1 \mathrm{pt} / 100 \mathrm{gal}$ & ++++ & 5 days & 7 days & $\begin{array}{l}\text { Diazinon is also effective } \\
\text { against small to medium-sized } \\
\text { caterpillars. }\end{array}$ \\
\hline & $\begin{array}{l}\text { Zeta- } \\
\text { cypermethrin } \\
\text { (Mustang } \mathrm{Max}^{\mathrm{TM}} \text { ) }\end{array}$ & $4 \mathrm{oz}$ & ++++ & $12 \mathrm{~h}$ & $24 \mathrm{~h}$ & $\begin{array}{l}\text { Use a minimum spray volume of } \\
20 \text { gal by ground. }\end{array}$ \\
\hline & $\begin{array}{l}\text { Acetamiprid } \\
\text { (Assail }^{\circledR} \text { 30SG) }\end{array}$ & $2.4 \mathrm{oz}$ & +++ & $12 \mathrm{~h}$ & 1 day & $\begin{array}{l}\text { Do not make more than four } \\
\text { applications per season. }\end{array}$ \\
\hline \multirow[t]{5}{*}{ Flower thrips } & $\begin{array}{l}\text { Spinetoram } \\
\text { (Delegate }^{\circledR} \text { WG) }\end{array}$ & $6 \mathrm{oz}$ & +++ & $4 \mathrm{~h}$ & 3 days & $\begin{array}{l}\text { Do not apply more than } 19.5 \\
\text { oz of Delegate or } 0.3 \mathrm{lb} \text { a.i. } \\
\text { spinetoram per acre per season. } \\
\text { Delegate }{ }^{\circledR} \text { WG is toxic to bees } \\
\text { until } 3 \mathrm{~h} \text { after application when } \\
\text { it is thoroughly dry. }\end{array}$ \\
\hline & $\begin{array}{l}\text { Flupyradifurone } \\
\text { (Sivanto }^{\circledast} 200 \text { SL) }\end{array}$ & 2-4 fl oz/acre & +++ & $4 \mathrm{~h}$ & 3 days & $\begin{array}{l}\text { Sivanto }^{\circledR} \text { You should allow a } \\
\text { minimum of } 7 \text { days between } \\
\text { applications. }\end{array}$ \\
\hline & $\begin{array}{l}\text { Spinosad } \\
\left.\text { (Entrust }^{\oplus}\right) \\
\text { Labeled for } \\
\text { organic use }\end{array}$ & $1.25-2 \mathrm{oz}$ & +++ & $4 \mathrm{~h}$ & 3 days & $\begin{array}{l}\text { Entrust is toxic to bees until it } \\
\text { is thoroughly dry ( } 3 \text { hours), but } \\
\text { thereafter it is relatively nontoxic } \\
\text { to bees. Entrust should be } \\
\text { applied in early morning or late } \\
\text { evening during bloom. }\end{array}$ \\
\hline & $\begin{array}{l}\text { Acetamiprid } \\
\text { (Assail }^{\circledast} 30 \text { SG) }\end{array}$ & $4.5-5.3 \mathrm{oz}$ & +++ & $12 \mathrm{~h}$ & 1 day & $\begin{array}{l}\text { Do not apply Assail }{ }^{\oplus} \text { during } \\
\text { bloom. It is an excellent } \\
\text { prebloom spray. Application can } \\
\text { be made } 7 \text { days prior to bloom. } \\
\text { Assail }{ }^{\circledR} \text { may negatively affect } \\
\text { pollinating bees; therefore, } \\
\text { application should be made in } \\
\text { the late evening. Do not make } \\
\text { more than four applications per } \\
\text { season. }\end{array}$ \\
\hline & $\begin{array}{l}\text { Tolfenpyrad } \\
\left(\text { Apta }^{\circledR}\right)\end{array}$ & $27 \mathrm{fl} \mathrm{oz/acre}$ & ++++ & $12 \mathrm{~h}$ & 3 days & $\begin{array}{l}\text { Allow } 14 \text { days between } \\
\text { applications. }\end{array}$ \\
\hline Imported fire ants & $\begin{array}{l}\text { Diazinon } \\
\text { (Diazinon AG500) }\end{array}$ & $1 \mathrm{pt} / 100 \mathrm{gal}$ & ++++ & $24 \mathrm{~h}$ & 7 days & $\begin{array}{l}\text { Mound drench. Slowly apply } 1 \\
\text { gal of diluted mixture over and } \\
6 \text { inches around each mound. } \\
\text { Apply gently to avoid disturbing } \\
\text { ants. }\end{array}$ \\
\hline
\end{tabular}




\begin{tabular}{|c|c|c|c|c|c|c|}
\hline Pest & $\begin{array}{l}\text { Management } \\
\text { Options }\end{array}$ & $\begin{array}{l}\text { Amount of } \\
\text { Formulation } \\
\text { per Acre }\end{array}$ & $\begin{array}{c}\text { Effectiveness } \\
\text { (Least }=+ \text { to } \\
\text { Most }=+++++)\end{array}$ & $\begin{array}{l}\text { Restricted } \\
\text { Entry Interval } \\
\quad \text { (REI) }\end{array}$ & $\begin{array}{l}\text { Postharvest } \\
\text { Interval } \\
\text { (PHI) }\end{array}$ & Comments \\
\hline & $\begin{array}{l}\text { Pyriproxyfen } \\
\text { (Esteem }^{\circledast} 0.86 \mathrm{EC} \\
\text { Ant Bait) }\end{array}$ & $\begin{array}{l}1.5-2.0 \mathrm{lb} \\
(2-4 \mathrm{tbsp} / \\
\text { mound) }\end{array}$ & ++++ & $12 \mathrm{~h}$ & $24 \mathrm{~h}$ & $\begin{array}{l}\text { Esteem }{ }^{\circledast} \text { Ant Bait should be } \\
\text { applied during the spring and, } \\
\text { if needed, again in the fall. } \\
\text { Apply on sunny days when } \\
\text { the soil temperature is at least } \\
60^{\circ} \mathrm{F} \text { and the soil is moist. Baits } \\
\text { are slow acting but effective. } \\
\text { Allow } 4 \text { weeks to work. Do } \\
\text { not make other imported fire } \\
\text { ant treatments for } 7-10 \text { days. } \\
\text { May need to reapply if heavy, } \\
\text { flooding rains occur within } 7 \\
\text { days. }\end{array}$ \\
\hline & $\begin{array}{l}\text { Methoprene } \\
\text { (Extinguish } \\
\text { Professional Fire } \\
\text { Ant Bait 0.5\%) }\end{array}$ & $\begin{array}{l}1-1.5 \mathrm{lb} \\
(3-5 \mathrm{tbsp} / \\
1000 \mathrm{sq} \mathrm{ft}) \\
(3-5 \mathrm{tbsp} / \\
\text { mound) }\end{array}$ & +++ & $4 \mathrm{~h}$ & 0 days & $\begin{array}{l}\text { Extinguish }{ }^{\circledast} \text { Professional Fire } \\
\text { Ant Bait ( } 0.5 \% \text { methoprene) } \\
\text { is legal for use on crop } \\
\text { land. Caution: Extinguish } \\
\text { baits with methoprene } \\
\text { plus hydramethylnon are } \\
\text { not labeled for use on crop } \\
\text { land. Application during the } \\
\text { heat of the day or when rain } \\
\text { is expected within } 6 \text { hours of } \\
\text { application will reduce the } \\
\text { effectiveness of this product. In } \\
\text { areas of heavy infestation, repeat } \\
\text { applications may be necessary } \\
10-12 \text { weeks after the initial } \\
\text { application. }\end{array}$ \\
\hline \multirow[t]{4}{*}{ Scale } & $\begin{array}{l}\text { Diazinon } \\
\text { (Diazinon AG500) }\end{array}$ & $1 \mathrm{pt} / 100 \mathrm{gal}$ & +++ & 5 days & 5 days & \\
\hline & $\begin{array}{l}\text { Pyriproxyfen } \\
\left.\text { (Esteem }^{\circledast} 0.86 \mathrm{EC}\right)\end{array}$ & $1.5-2.0 \mathrm{lb}$ & +++ & $12 \mathrm{~h}$ & $24 \mathrm{~h}$ & \\
\hline & $\begin{array}{l}\text { Mineral oil (JMS } \\
\text { Stylet oil) }\end{array}$ & $25-150 \mathrm{gal}$ & ++ & $4 \mathrm{~h}$ & $12 \mathrm{~h}$ & $\begin{array}{l}\text { Recommended } 1-3 \text { gallons per } \\
100 \text { gallons of water. Avoid using } \\
\text { this product if the temperature } \\
\text { is above } 85^{\circ} \mathrm{F} \text {. }\end{array}$ \\
\hline & $\begin{array}{l}\text { Imidacloprid } \\
\text { (Admire }{ }^{\circledast} \text { Pro) }\end{array}$ & $10 \mathrm{fl} \mathrm{oz}$ & +++ & $12 \mathrm{~h}$ & 3 days & Foliar application. \\
\hline \multirow[t]{5}{*}{ Spider mites } & $\begin{array}{l}\text { Fenazaquin } \\
\text { (Magister }^{\circledast} \text { SC) }\end{array}$ & $24-36$ fl oz & ++++ & $12 \mathrm{~h}$ & 7 days & $\begin{array}{l}\text { Apply in at least } 50 \text { gallons of } \\
\text { water per acre. Use higher rates } \\
\text { for heavier mite pressure. Do not } \\
\text { make more than one application } \\
\text { per year. }\end{array}$ \\
\hline & $\begin{array}{l}\text { Fenpyroximate } \\
\left.\text { (Portal }^{\circledR}\right)\end{array}$ & $2 \mathrm{pt}$ & ++++ & $12 \mathrm{~h}$ & 1 day & $\begin{array}{l}\text { Growers can make two } \\
\text { applications per year. }\end{array}$ \\
\hline & $\begin{array}{l}\text { Acequinocyl } \\
\text { (Kanemite }^{\circledR} 15 \text { SC) }\end{array}$ & $31 \mathrm{fl} \mathrm{oz}$ & +++ & $12 \mathrm{~h}$ & 1 day & $\begin{array}{l}\text { Do not apply this product } \\
\text { through the irrigation system. } \\
\text { Allow a minimum of } 21 \text { days } \\
\text { between applications. }\end{array}$ \\
\hline & $\begin{array}{l}\text { Horticultural oil } \\
\left.\text { (JMS Stylet-Oil }^{\circledR}\right)\end{array}$ & $3-6 \mathrm{qt} / 100 \mathrm{gal}$ & ++ & $4 \mathrm{~h}$ & 0 days & $\begin{array}{l}\text { Avoid using this product if the } \\
\text { temperature is above } 85^{\circ} \mathrm{F} \text {. }\end{array}$ \\
\hline & $\begin{array}{l}\text { Horticultural oil } \\
\text { (Stoller Golden } \\
\text { Pest Spray Oil) }\end{array}$ & $\begin{array}{l}2 \text { gal (low } \\
\text { volume) } \\
\text { application or } \\
2 \text { gal/100 gal } \\
\text { (dilute spray) }\end{array}$ & ++ & $4 \mathrm{~h}$ & 0 days & $\begin{array}{l}\text { Avoid using this product if the } \\
\text { temperature is above } 85^{\circ} \mathrm{F} \text {. }\end{array}$ \\
\hline
\end{tabular}




\begin{tabular}{|c|c|c|c|c|c|c|}
\hline Pest & $\begin{array}{l}\text { Management } \\
\text { Options }\end{array}$ & $\begin{array}{l}\text { Amount of } \\
\text { Formulation } \\
\text { per Acre }\end{array}$ & $\begin{array}{c}\text { Effectiveness } \\
\text { (Least }=+ \text { to } \\
\text { Most }=+++++)\end{array}$ & $\begin{array}{l}\text { Restricted } \\
\text { Entry Interval } \\
\text { (REI) }\end{array}$ & $\begin{array}{l}\text { Postharvest } \\
\text { Interval } \\
\text { (PHI) }\end{array}$ & Comments \\
\hline \multirow[t]{10}{*}{$\begin{array}{l}\text { Spotted wing } \\
\text { drosophila }\end{array}$} & $\begin{array}{l}\text { Zeta- } \\
\text { cypermethrin } \\
\text { (Mustang } \mathrm{Max}^{\mathrm{TM}} \text { ) }\end{array}$ & $4 \mathrm{oz}$ & ++++ & $12 \mathrm{~h}$ & $24 \mathrm{~h}$ & $\begin{array}{l}\text { Use a minimum spray volume of } \\
20 \text { gal by ground. }\end{array}$ \\
\hline & $\begin{array}{l}\text { Spinetoram } \\
\text { (Delegate }{ }^{\circledR} \text { WG) }\end{array}$ & $6 \mathrm{oz}$ & +++ & $4 \mathrm{~h}$ & 3 days & $\begin{array}{l}\text { Delegate }{ }^{\circledR} \text { WG is toxic to bees } \\
\text { until it is thoroughly dry. }\end{array}$ \\
\hline & $\begin{array}{l}\text { Malathion } \\
\text { (Malathion } 57 \mathrm{EC} \text { ) }\end{array}$ & $1.5 \mathrm{pt}$ & ++++ & $12 \mathrm{~h}$ & 1 day & \\
\hline & $\begin{array}{l}\text { Cyantraniliprole } \\
\left(\text { Exirel }^{\circledR}\right)\end{array}$ & $13.5-20.5 \mathrm{oz}$ & +++ & $12 \mathrm{~h}$ & 3 days & $\begin{array}{l}\text { Minimum application interval } \\
\text { between treatments is } 5 \text { days. }\end{array}$ \\
\hline & $\begin{array}{l}\text { Fenpropathrin } \\
\left.\text { (Danitol }^{\circledast} 2.4 \mathrm{EC}\right)\end{array}$ & $10.6-16 \mathrm{oz}$ & ++++ & $24 \mathrm{~h}$ & 3 days & $\begin{array}{l}\text { Do not make more than two } \\
\text { consecutive applications. Rotate } \\
\text { with insecticides from different } \\
\text { classes. }\end{array}$ \\
\hline & $\begin{array}{l}\text { Bifenthrin } \\
\text { (Brigade }^{\circledR} 2 \mathrm{EC} \text { ) }\end{array}$ & $5.3-16 \mathrm{oz}$ & ++++ & $12 \mathrm{~h}$ & 1 day & $\begin{array}{l}\text { Do not make more than two } \\
\text { consecutive applications. }\end{array}$ \\
\hline & $\begin{array}{l}\text { Phosmet (Imidan }{ }^{\circledast} \\
70-W)\end{array}$ & $1.3 \mathrm{lb}$ & ++++ & 1 day & 3 days & \\
\hline & $\begin{array}{l}\text { Spinosad } \\
\text { (Entrust }^{\oplus} \text { ) } \\
\text { (labeled for } \\
\text { organic use) }\end{array}$ & $1.25-2 \mathrm{oz}$ & +++ & $4 \mathrm{~h}$ & 3 days & $\begin{array}{l}\text { Label for organic use. Allow } \\
\text { pesticide to dry before bees can } \\
\text { forage. }\end{array}$ \\
\hline & $\begin{array}{l}\text { Acetamiprid } \\
\left.\text { (Assail }^{\oplus} 30 \mathrm{SG}\right)\end{array}$ & $4.5-5.3 \mathrm{oz}$ & +++ & $12 \mathrm{~h}$ & 1 day & $\begin{array}{l}\text { Do not apply when a lot of bees } \\
\text { are foraging. }\end{array}$ \\
\hline & $\begin{array}{l}\text { Tolfenpyrad } \\
\left(\text { Apta }^{\circledR}\right)\end{array}$ & $27 \mathrm{fl} \mathrm{oz/acre}$ & ++ & $12 \mathrm{~h}$ & 3 days & $\begin{array}{l}\text { Allow } 14 \text { days between } \\
\text { applications. }\end{array}$ \\
\hline $\begin{array}{l}\text { White grubs } \\
\text { (Grubs of Asiatic } \\
\text { garden beetle, } \\
\text { European and } \\
\text { masked chafer, } \\
\text { and Oriental } \\
\text { beetle) }\end{array}$ & $\begin{array}{l}\text { Imidacloprid } \\
\text { (Admire }{ }^{\circledR} \text { Pro) }\end{array}$ & $10 \mathrm{fl} \mathrm{oz}$ & +++ & $12 \mathrm{~h}$ & 7 days & $\begin{array}{l}\text { Soil application. Chemigation } \\
\text { into root zone through low- } \\
\text { pressure drip, trickle, or } \\
\text { microsprinkler. It is important } \\
\text { to moisten the soil ( } 1 / 2-1 \text { inch } \\
\text { of water) prior to application or } \\
\text { shortly after application. }\end{array}$ \\
\hline $\begin{array}{l}\text { Yellownecked } \\
\text { caterpillars }\end{array}$ & $\begin{array}{l}\text { Malathion } \\
\text { (Malathion } 57 \mathrm{EC} \text { ) }\end{array}$ & $1.5 \mathrm{pt}$ & +++ & $12 \mathrm{~h}$ & 1 day & $\begin{array}{l}\text { Foliage-feeding caterpillars } \\
\text { become more difficult to control } \\
\text { as they mature. }\end{array}$ \\
\hline
\end{tabular}


Table 3. Efficacy of selected fungicides against blueberry diseases.

\begin{tabular}{|c|c|c|c|c|c|c|c|c|}
\hline $\begin{array}{c}\text { Fungicide } \\
\text { [Mode of Action] }\end{array}$ & $\begin{array}{c}\text { Phytoph- } \\
\text { thora Root } \\
\text { Rot }\end{array}$ & $\begin{array}{c}\text { Botrytis } \\
\text { (Gray Mold) }\end{array}$ & $\begin{array}{c}\text { Alternaria } \\
\text { Rot }\end{array}$ & $\begin{array}{l}\text { Phomopsis } \\
\text { Twig Blight }\end{array}$ & $\begin{array}{c}\text { Ripe Rot } \\
\text { (Anthrac- } \\
\text { nose) }\end{array}$ & $\begin{array}{l}\text { Septoria } \\
\text { Leaf Spot }\end{array}$ & $\begin{array}{l}\text { Anthrac- } \\
\text { nose Leaf } \\
\text { Spot }\end{array}$ & Rust \\
\hline $\begin{array}{l}\text { Azoxystrobin } \\
\left(\text { Abound }^{\oplus}\right)[11]\end{array}$ & NA & NA & +++++ & ++ & +++++ & ++++ & ++++ & $? ? ?$ \\
\hline $\begin{array}{l}\text { Captan (Captan) } \\
\text { [M4] }\end{array}$ & NA & ++ & ++ & ++ & +++ & ++ & +++ & NA \\
\hline $\begin{array}{l}\text { Chlorothalonil } \\
\left(\text { Bravo }^{\oplus}\right) \text { [M5] }\end{array}$ & $\begin{array}{l}\text { NA } \\
\text { Do not } \\
\text { use before } \\
\text { harvest. }\end{array}$ & $\begin{array}{l}\text { NA } \\
\text { Do not } \\
\text { use before } \\
\text { harvest. }\end{array}$ & $\begin{array}{l}\text { NA } \\
\text { Do not } \\
\text { use before } \\
\text { harvest. }\end{array}$ & $\begin{array}{l}\text { NA } \\
\text { Do not } \\
\text { use before } \\
\text { harvest. }\end{array}$ & $\begin{array}{l}\text { NA } \\
\text { Do not } \\
\text { use before } \\
\text { harvest. }\end{array}$ & $\begin{array}{l}++++ \\
\text { Do not } \\
\text { use before } \\
\text { harvest. }\end{array}$ & $\begin{array}{l}\text { ??? } \\
\text { Do not } \\
\text { use before } \\
\text { harvest. }\end{array}$ & $\begin{array}{l}+++ \\
\text { Do not } \\
\text { use before } \\
\text { harvest. }\end{array}$ \\
\hline $\begin{array}{l}\text { Cyprodinil + } \\
\text { fludioxonil } \\
\left(\text { Switch }^{\circledast}\right)[9+12]\end{array}$ & NA & +++++ & +++++ & +++ & +++++ & +++ & ++++ & $? ? ?$ \\
\hline $\begin{array}{l}\text { Fenbuconazole } \\
\left(\text { Indar }{ }^{\circledast}\right)^{*}[3] \\
{ }^{*} \text { tank mix with } \\
\text { captan products } \\
\text { during bloom to } \\
\text { prevent fruit rots }\end{array}$ & NA & NA & NA & NA & NA & ++++ & NA & +++ \\
\hline $\begin{array}{l}\text { Fenhexamid } \\
\left(\text { Elevate }^{\circledR}\right) \text { [17] }\end{array}$ & NA & ++++ & NA & NA & NA & NA & NA & NA \\
\hline $\begin{array}{l}\text { Fluazinam } \\
\left.\text { (Omega }{ }^{\circledR} 500 \mathrm{~F}\right) \\
{[29]}\end{array}$ & NA & ++ & ++ & +++ & +++ & NA & NA & NA \\
\hline $\begin{array}{l}\text { Fluopyram + } \\
\text { pyrimethanil } \\
\left(\text { Luna Tranquility }{ }^{\circledast}\right) \\
{[7+9]}\end{array}$ & NA & $?$ & $?$ & NA & NA & $?$ & $?$ & NA \\
\hline $\begin{array}{l}\text { Fosetyl-Al } \text { Aliette }^{\circledR} \\
\text { WDG) [33] }\end{array}$ & +++ & NA & NA & + & + & ++++ & +++ & NA \\
\hline $\begin{array}{l}\text { Mefenoxam } \\
\left(\text { Ridomil Gold }^{\circledR} \text { ) [4] }\right.\end{array}$ & +++ & NA & NA & NA & NA & NA & NA & NA \\
\hline $\begin{array}{l}\text { Metconazole } \\
\left(\text { Quash }^{\circledast}\right)[3]\end{array}$ & NA & ??? & $? ? ?$ & ++++ & ??? & ++++ & ++++ & ++++ \\
\hline $\begin{array}{l}\text { Mono- and } \\
\text { dipotassium salts } \\
\text { of phosphorous } \\
\text { acid (K-Phite }^{\circledR} \text { ) [33] }\end{array}$ & +++ & NA & NA & NA & NA & ++++ & ++++ & NA \\
\hline $\begin{array}{l}\text { Potassium } \\
\text { phosphite } \\
\text { (ProPhyt }^{\oplus} \text { ) [33] }\end{array}$ & +++ & NA & NA & NA & NA & ++++ & ++++ & NA \\
\hline $\begin{array}{l}\text { Propiconazole } \\
\text { (Tilt }^{\circledR}, \text { Bumper }^{\circledast}, \\
\text { PropiMax }^{\circledast}[3]\end{array}$ & NA & NA & NA & NA & NA & ++++ & $? ? ?$ & +++ \\
\hline $\begin{array}{l}\text { Prothioconazole } \\
\left(\text { Proline }^{\circledast}\right)[3]\end{array}$ & NA & NA & NA & ??? & ??? & ++++ & $? ? ?$ & ++++ \\
\hline $\begin{array}{l}\text { Pyraclostrobin } \\
+ \text { boscalid } \\
\left.\text { (Pristine }^{\circledast}\right)[11+7]\end{array}$ & NA & +++ & +++++ & +++ & +++++ & +++++ & +++++ & +++++ \\
\hline Ziram (Ziram) [M3] & NA & ++ & + & +++ & +++ & ??? & ++ & ??? \\
\hline
\end{tabular}


Table 4. Fungicide classes with moderate to high risk of resistance development (generally single sites of action).

\begin{tabular}{|c|c|c|}
\hline \multicolumn{2}{|c|}{ Fungicide Class } & Trade Name and Chemical Name \\
\hline \multicolumn{2}{|c|}{ Anilino-pyrimidines [9] } & $\begin{array}{l}\text { Switch }{ }^{\circledast} \text { (cyprodinil; one component of a two-part mixture), Luna Tranquility } \\
\text { (pyrimethanil; one component) }\end{array}$ \\
\hline \multicolumn{2}{|c|}{ Succinate dehydrogenase inhibitors (SDHI) [7] } & Pristine $^{\circledast}$ (boscalid; one component); Luna Tranquility ${ }^{\circledast}$ (fluopyram; one component) \\
\hline \multicolumn{2}{|c|}{ Demethylation inhibitors (DMIs) or sterol inhibitors [3] } & $\begin{array}{l}\text { Indar }{ }^{\circledast} \text { (fenbuconazole), Tilt }{ }^{\oplus} \text { (propiconazole), } \text { Proline }^{\circledast} \text { (prothioconazole), Quash }{ }^{\circledast} \\
\text { (metconazole) }\end{array}$ \\
\hline \multicolumn{2}{|c|}{ 2,6-dinitroanilines [29] } & Omega $^{\circledast}$ (fluazinam) \\
\hline \multicolumn{2}{|l|}{ Hydroxyanilides [17] } & Elevate $^{\circledast}$ (fenhexamid) \\
\hline \multicolumn{2}{|l|}{ Phenylamides [4] } & Ridomil Gold ${ }^{\circledast}$ (mefenoxam) \\
\hline \multicolumn{2}{|l|}{ Phenylpyrroles [12] } & Switch $^{\circledast}$ (fludioxanil; one component) \\
\hline \multicolumn{2}{|c|}{ Strobilurins or Qol (quinone outside inhibitors) [11] } & Abound $^{\circledast}$ (azoxystrobin) \\
\hline Fungicide Class & \multicolumn{2}{|r|}{ Trade Name and Chemical Name } \\
\hline Coppers & \multicolumn{2}{|l|}{ Coppers (numerous formulations) } \\
\hline Dithiocarbamates & \multicolumn{2}{|l|}{ Ziram (Ziram) } \\
\hline Phthalimides & \multicolumn{2}{|l|}{ Captan (Captan) } \\
\hline Phthalonitriles & \multicolumn{2}{|l|}{ Bravo $^{\circledast}$ (Chlorothalonil) } \\
\hline Phosphonates & \multicolumn{2}{|c|}{ Aliette $^{\circledast}$ (Fosetyl-Al), K-Phite ${ }^{\circledast}$ (Mono- and dipotassium salts of phosphorous acid), ProPhyt $^{\circledast}$ (Potassium phosphite) } \\
\hline
\end{tabular}


Table 6. Seasonal "at a glance" fungicidal spray schedule options for blueberry.

\begin{tabular}{|c|c|c|c|c|c|c|c|}
\hline $\begin{array}{l}\text { Developmental } \\
\text { Stage }\end{array}$ & Green Tip & $\begin{array}{l}\text { Bloom (2-3 } \\
\text { Applications) }^{b}\end{array}$ & Petal Fall & $\begin{array}{l}\text { 10-14 Days } \\
\text { after Petal Fall }\end{array}$ & $\begin{array}{l}\text { 20-24 Days } \\
\text { after Petal Fall }\end{array}$ & Preharvest & Postharvest \\
\hline $\begin{array}{l}\text { Disease } \\
\text { controlled } \\
\text { (Fungicides) }\end{array}$ & $\begin{array}{l}\text { Twig blight } \\
\text { (Pristine }^{\circledR \mathrm{a}} \text { or } \\
\left.\text { Indar }{ }^{\otimes}\right)\end{array}$ & 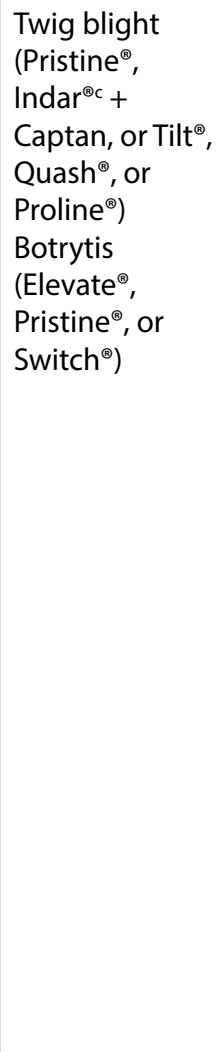 & $\begin{array}{l}\text { Alternaria } \\
\text { and ripe rots } \\
\text { (Abound }^{\oplus}, \\
\text { Pristine } \\
\text { Switch }^{\oplus} \text {, } \\
\text { Captan, or } \\
\left.\text { Omega }^{\oplus}\right)^{d}\end{array}$ & $\begin{array}{l}\text { Alternaria } \\
\text { and ripe rots } \\
\text { (Abound }^{\oplus} \text {, } \\
\text { Pristine }^{\oplus} \text {, } \\
\text { Switch }^{\oplus} \\
\text { Captan, or } \text { Omega }{ }^{\oplus} \text { ) }\end{array}$ & $\begin{array}{l}\text { Alternaria } \\
\text { and ripe rots } \\
\text { (Abound }^{\oplus} \text {, } \\
\text { Pristine }^{\oplus} \text {, } \\
\text { Switch }^{\oplus} \text {, } \\
\text { Captan, or } \\
\text { Omega }{ }^{\oplus} \text { ) }\end{array}$ & 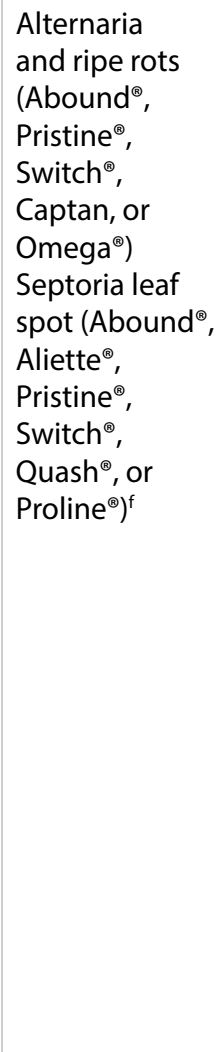 & 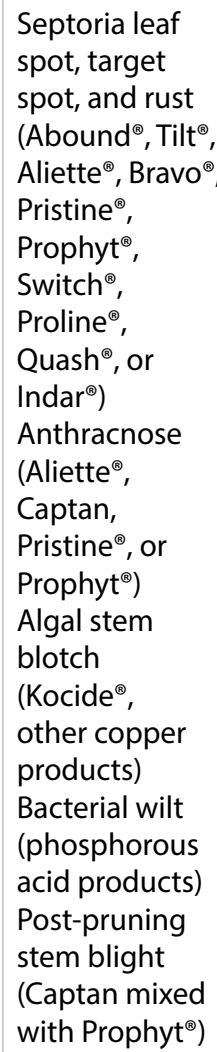 \\
\hline
\end{tabular}

a NOTE: No more than two sequential applications of Pristine ${ }^{\circledR}$ should be made before alternating with fungicides that have a different mode of action. Do not make more than four applications of Pristine ${ }^{\circledR}$ per acre per crop year. Mix Pristine ${ }^{\varpi}$ with only water for applications to blueberry. ${ }^{b}$ Bloom times vary because of varietal differences and the environment. Bloom sprays should provide protection against the primary bloom pathogens for the entire bloom period. The number of applications required for bloom may vary from one to three, depending on the season and the variety.

'When using Indar ${ }^{\circledR}$ during bloom, always tank mix with Captan. Captan provides additional mummy berry control, and it has some activity against twig blight, Botrytis, and fruit rots. However, it mainly prevents rots when used with Indar ${ }^{\circledR}$. It also provides resistance management. ${ }^{\mathrm{d}}$ Many of the fungicides registered for rot control may also have activity against twig dieback organisms, such as Phomopsis spp.

${ }^{\mathrm{e}}$ In wet years, preharvest and postharvest rots may be a potential problem. Under these conditions, one to two applications of a preharvest material may be necessary for rot control.

f Septoria leaf spot is generally controlled with two to four fungicide applications. This disease is more problematic on highbush blueberry varieties, but some rabbiteye varieties may experience premature defoliation from Septoria as well. For leaf spot, Aliette ${ }^{\circledR}$ and other phosphites (ProPhyt ${ }^{\oplus}$, etc.) are best used after harvest since they are not as efficacious against fruit rots, and they serve as a resistance management tool. ${ }^{g}$ Rust is problematic on some blueberry varieties, especially in Florida and south Georgia, and it can result in complete, premature defoliation on susceptible varieties. Scout for rust in mid to late July. Two to three applications of fungicides from August to mid-September will generally result in good rust management. Some varieties may require yearly rust control. 


\section{Weed Management Options}

Table 7. Preemergence chemical weed control for blueberry.

\begin{tabular}{|c|c|c|c|c|}
\hline $\begin{array}{c}\text { Common name } \\
\text { (lb a.i./A) }\end{array}$ & $\begin{array}{l}\text { Trade name } \\
\text { (product/A) }\end{array}$ & MOA & Crop age & Comments \\
\hline $\begin{array}{l}\text { Dichlobenil } \\
4-6 \\
1.96-3.9\end{array}$ & $\begin{array}{l}\left(\text { Casoron }^{\circledast}\right) 4 \mathrm{G} \\
100-150 \mathrm{lb} \\
\left(\text { Casoron }^{\oplus}\right) 1.4 \mathrm{CS} \\
1.4-2.8 \mathrm{gal}^{-}\end{array}$ & 20 & Bearing / nonbearing & $\begin{array}{l}\text { Annual and some perennial weeds } \\
\text { Casoron }{ }^{\circledast} 1.4 \text { CS must be applied to well-established } \\
\text { plantings and not until at least } 1 \text { year after transplanting. } \\
\text { Casoron }{ }^{\circledast} 4 \mathrm{G} \text { can be applied } 4 \text { weeks after transplanting. } \\
\text { Higher rates may be required to control perennial weed } \\
\text { species. }\end{array}$ \\
\hline $\begin{array}{l}\text { Diuron } \\
1.2-1.6\end{array}$ & $\begin{array}{l}\text { (Diuron, Karmex }{ }^{\circledast}, \\
\text { Karmex }^{\circledast} \text { XP) } 80 \text { WDG } \\
1.5-2.0 \mathrm{lb} \\
\left(\text { Direx }^{\circledast}\right) 4 \mathrm{~L} \\
1.2-1.6 \text { qt }\end{array}$ & 7 & Bearing / nonbearing & $\begin{array}{l}\text { Annual broadleaf and grass weeds } \\
\text { Bushes must be established at least } 1 \text { year from } \\
\text { transplanting. Direct spray solution to the base of the } \\
\text { bush to minimize contact with leaves, flowers, and } \\
\text { fruits. Diuron may be applied as a single application in } \\
\text { the spring (1.2-1.6 lb a.i./acre) and another application } \\
(1.2-1.6 \mathrm{lb} \text { a.i./acre) in the fall. }\end{array}$ \\
\hline $\begin{array}{l}\text { Flumioxazin } \\
0.188-0.38\end{array}$ & $\begin{array}{l}\left(\text { Chateau }^{\oplus}\right) 51 \text { WDG } \\
6-12 \mathrm{oz}\end{array}$ & 14 & Bearing / nonbearing & $\begin{array}{l}\text { Annual broadleaf and grass weeds } \\
\text { Direct spray solution to the base of the bush. Do not apply } \\
\text { to bushes less than } 2 \text { years old unless protected by a } \\
\text { nonporous wrap, grow tubes, or waxed cylinders. Do not } \\
\text { apply between bud break and final harvest. Do not apply } \\
\text { more than } 12 \text { oz in a } 12 \text {-month period. Do not apply more } \\
\text { than } 6 \text { oz per application to bushes less than } 3 \text { years old } \\
\text { in soils with sand plus gravel content greater than } 80 \% \text {. } \\
\text { Do not allow Chateau }{ }^{\circledast} \text { to come in contact with any green } \\
\text { tissue, or injury may occur. Chateau }{ }^{\circledR a y} \text { be applied in } \\
\text { sequential applications, but not within } 30 \text { days of each } \\
\text { other. }\end{array}$ \\
\hline $\begin{array}{l}\text { Isoxaben } \\
0.5-1.0\end{array}$ & $\begin{array}{l}\left.\text { (Gallery }{ }^{\circledR}, \text { Gallery }^{\circledR} \mathrm{T \& V}\right) \\
75 \mathrm{DF} \\
0.66-1.33 \mathrm{lb}\end{array}$ & 12 & Nonbearing & $\begin{array}{l}\text { Certain broadleaf weeds } \\
\text { Allow } 60 \text { days between applications and do not apply } \\
\text { more than } 4 \text { lb of product within a 12-month period. }\end{array}$ \\
\hline $\begin{array}{l}\text { Isoxaben+ } \\
\text { Oryzalin } \\
2.0-4.0+ \\
0.5-1\end{array}$ & $\begin{array}{l}\left.\text { (Snapshot }^{\oplus}\right) 2.5 \mathrm{TG} \\
100-200 \mathrm{lb}\end{array}$ & $12+3$ & Nonbearing & $\begin{array}{l}\text { Certain broadleaf and annual grass weeds. } \\
\text { A single rainfall or sprinkler irrigation of } 0.5 \text { in is necessary } \\
\text { within } 3 \text { days of application for optimum weed control. } \\
\text { Allow } 60 \text { days between applications of } 150 \mathrm{lb} \text { product/ } \\
\text { acre or greater. Do not apply more than } 600 \mathrm{lb} / \text { acre } \\
\text { product within a } 12 \text {-month period. Do not apply to } \\
\text { bushes that have wet foliage from rainfall or dew. }\end{array}$ \\
\hline $\begin{array}{l}\text { Mesotrione } \\
0.09-0.19\end{array}$ & $\begin{array}{l}\left(\text { Callisto }{ }^{\circledR}\right) 4 \mathrm{~L} \\
\text { 3-6 fl oz }\end{array}$ & 27 & Bearing / nonbearing & $\begin{array}{l}\text { Annual broadleaf weeds } \\
\text { Apply before prebloom, or illegal residues may occur. } \\
\text { Can be applied as a split application of } 3 \text { oz followed by } 3 \\
\text { oz with no less than } 14 \text { days between applications. Limit } \\
\text { contact with green foliage and stems, or injury may result. } \\
\text { Include a crop oil concentrate at } 1 \% \text { v/v. UF/IFAS has } \\
\text { conducted limited testing; thus, any application should } \\
\text { be made on a small acreage first to determine cultivar } \\
\text { tolerance. }\end{array}$ \\
\hline $\begin{array}{l}\text { Napropamide } \\
4\end{array}$ & $\begin{array}{l}\left(\text { Devrinol }^{\oplus}\right) 50 \mathrm{DF} \\
8 \mathrm{Ib}^{-} \\
\left(\text {Devrinol }^{\oplus}\right) 10 \mathrm{G} \\
40 \mathrm{lb}\end{array}$ & 15 & Bearing / nonbearing & $\begin{array}{l}\text { Small-seed broadleaf and annual grass weeds } \\
\text { Do not apply within } 1 \text { year of planting. Direct spray } \\
\text { solution to the base of the bush to minimize contact } \\
\text { with foliage and fruit. Applications should be made to a } \\
\text { weed-free surface. Napropamide should be cultivated or } \\
\text { irrigated to a depth of } 2 \text { in within } 24 \text { hours of application. }\end{array}$ \\
\hline $\begin{array}{l}\text { Norflurazon } \\
2-4\end{array}$ & $\begin{array}{l}\left(\text { Solicam }^{\oplus}\right) 80 \text { WDG } \\
2.5-5.0 \mathrm{lb}\end{array}$ & 12 & Bearing / nonbearing & $\begin{array}{l}\text { Small-seed broadleaf and annual grass weeds } \\
\text { PHI } 60 \text { days } \\
\text { Consult label for amount of formulation based on soil } \\
\text { texture. Do not apply within } 6 \text { months of planting. Rainfall } \\
\text { or irrigation is required within } 4 \text { weeks of application. }\end{array}$ \\
\hline
\end{tabular}




\begin{tabular}{|c|c|c|c|c|}
\hline $\begin{array}{l}\text { Common name } \\
\text { (Ib a.i./A) }\end{array}$ & $\begin{array}{l}\text { Trade name } \\
\text { (product/A) }\end{array}$ & MOA & Crop age & Comments \\
\hline $\begin{array}{l}\text { Oryzalin } \\
2-4\end{array}$ & $\begin{array}{l}\left.\text { (Oryzalin, Surflan }{ }^{\oplus}\right) 4 \\
\text { AS } \\
2-4 \text { qt }\end{array}$ & 3 & Bearing / nonbearing & $\begin{array}{l}\text { Certain broadleaf and annual grass weeds } \\
\text { Irrigation or rain event of } 0.5-1 \text { in is required within } 1 \\
\text { week of application. }\end{array}$ \\
\hline $\begin{array}{l}\text { Pronamide } \\
1-2\end{array}$ & $\begin{array}{l}\left(\mathrm{Kerb}^{\oplus}\right) 50 \mathrm{~W} \\
2-4 \mathrm{lb}\end{array}$ & 3 & Bearing / nonbearing & $\begin{array}{l}\text { Certain broadleaf and grass weeds } \\
\text { Apply in the fall or early winter when temperature is less } \\
\text { than } 55^{\circ} \mathrm{F} \text { for maximum efficacy. Do not apply to newly } \\
\text { planted bushes; wait for root establishment. Immediately } \\
\text { follow application with rainfall or irrigation for additional } \\
\text { weed control. Do not apply more than } 4 \mathrm{lb} \text { product/acre } \\
\text { or more than one application in } 1 \text { year. }\end{array}$ \\
\hline $\begin{array}{l}\text { Simazine } \\
2-4\end{array}$ & $\begin{array}{l}\left(\text { Princep }{ }^{\oplus}\right) 90 \text { WDG } \\
2.2-4.4 \mathrm{lb} \\
\text { (Princep }) 4 \mathrm{~L} \\
2-4 \mathrm{qt}\end{array}$ & 5 & Bearing / nonbearing & $\begin{array}{l}\text { Annual broadleaf and grass weeds } \\
\text { Do not apply more than } 1 \mathrm{lb} \text { a.i./acre on plantings less } \\
\text { than } 6 \text { months old. Apply half the maximum in the spring } \\
\text { before bud break and half in the fall. }\end{array}$ \\
\hline $\begin{array}{l}\text { Terbacil (5) } \\
0.4-1.6\end{array}$ & $\begin{array}{l}\left(\text { Sinbar }{ }^{\oplus}\right) 80 \mathrm{WP} \\
0.5-2 \mathrm{lb}\end{array}$ & 5 & Bearing / nonbearing & $\begin{array}{l}\text { Annual broadleaf and grass weeds } \\
\text { Only apply to bushes that have been planted for } 1 \text { year } \\
\text { or longer. Do not use in soils with less than } 3 \% \text { organic } \\
\text { matter. Use in the spring or after harvest before weeds } \\
\text { emerge or shortly after. }\end{array}$ \\
\hline
\end{tabular}


Table 8. Postemergence chemical weed control in blueberry.

\begin{tabular}{|c|c|c|c|c|}
\hline $\begin{array}{c}\text { Common Name } \\
\text { (Ib a.i./A) }\end{array}$ & $\begin{array}{l}\text { Trade Name } \\
\text { (product/A) }\end{array}$ & MOA & Crop Age & Comments \\
\hline $\begin{array}{l}\text { Carfentrazone } \\
0.016-0.031\end{array}$ & $\begin{array}{l}\left(\operatorname{Aim}^{\circledast}\right) 2 \mathrm{EC} \\
1-2 \mathrm{fl} \mathrm{oz} \\
\left(\mathrm{Aim}^{\circledast}\right) 1.9 \mathrm{EW} \\
1-2 \mathrm{fl} \mathrm{oz}\end{array}$ & 14 & Bearing / nonbearing & $\begin{array}{l}\text { Broadleaf weeds } \\
\text { Direct spray solution to the base of the bush to minimize } \\
\text { contact with green stems, leaves, flowers, and fruits. Coverage } \\
\text { is essential; use a minimum of } 20 \text { gal of spray solution per acre. } \\
\text { Include a nonionic surfactant, methylated seed oil, or crop oil } \\
\text { concentrate; see label for rate. Do not apply more than } 0.031 \\
\text { lb a.i./A during the dormant stage, } 0.064 \mathrm{lb} \text { a.i./acre during } \\
\text { the growing stage, and more than } 0.096 \mathrm{lb} \text { a.i./acre per crop } \\
\text { season. }\end{array}$ \\
\hline $\begin{array}{l}\text { Clethodim } \\
0.07-0.13\end{array}$ & $\begin{array}{l}\left(\text { Select Max }{ }^{\circledast}\right) 2 \text { EC } \\
9-16 \mathrm{fl} \mathrm{oz}^{-}\end{array}$ & 1 & Bearing / nonbearing & $\begin{array}{l}\text { Annual and perennial grass weeds } \\
\text { The spray solution should include a nonionic surfactant at } \\
0.25 \% \mathrm{v} / \mathrm{v} \text {. Do not apply within } 14 \text { days of harvest. }\end{array}$ \\
\hline $\begin{array}{l}\text { Diuron } \\
1.2-1.6\end{array}$ & $\begin{array}{l}\text { (Diuron, Karmex }^{\circledast} \text {, or } \\
\text { Karmex }^{\circledR} \text { XP) } 80 \text { WDG } \\
1.5-2 \mathrm{lb} \\
\left(\text { Direx }^{\circledast}\right) 4 \mathrm{~L} \\
1.2-1.6 \text { qt }\end{array}$ & 7 & Bearing / nonbearing & $\begin{array}{l}\text { Annual broadleaf and grass weeds } \\
\text { Use at least } 1 \text { year from transplanting. Direct spray solution to } \\
\text { the base of the bush to minimize contact with leaves, flowers, } \\
\text { and fruits. Diuron may be applied as a single application in the } \\
\text { spring ( } 1.2-1.6 \mathrm{qt} / \mathrm{acre}) \text { and another application }(1.2-1.6 \mathrm{qt} / \\
\text { acre) in the fall. Read labels for restrictions on soil type. Include } \\
\text { surfactant at } 0.25 \% \mathrm{v} / \mathrm{v} \text { or crop oil concentration at } 1.0 \% \mathrm{v} / \mathrm{v} \text { to } \\
\text { improve postemergence weed control. }\end{array}$ \\
\hline $\begin{array}{l}\text { Diquat } \\
0.7-0.9\end{array}$ & $\begin{array}{l}\text { (Diquat) } 2 \mathrm{~L} \\
1.5-2.0 \mathrm{pt}\end{array}$ & 22 & Nonbearing & $\begin{array}{l}\text { Broadleaf and grass weeds } \\
\text { Direct spray to the base of the bush to minimize contact with } \\
\text { green stems and foliage. Include a nonionic surfactant at } \\
0.06 \%-0.5 \% \mathrm{v} / \mathrm{v} \text {. }\end{array}$ \\
\hline $\begin{array}{l}\text { Fluazifop } \\
0.25-0.375\end{array}$ & $\begin{array}{l}\text { (Fusilade }{ }^{\circledR} \text { DX) } 2 \text { EC } \\
16-24 \mathrm{fl} \mathrm{oz}\end{array}$ & 1 & Nonbearing & $\begin{array}{l}\text { Annual and perennial grass weeds } \\
\text { Include nonionic surfactant at } 0.25 \%-0.5 \% \mathrm{v} / \mathrm{v} \text { or crop oil } \\
\text { concentrate at } 1 \% \mathrm{v} / \mathrm{v} \text {. }\end{array}$ \\
\hline $\begin{array}{l}\text { Glufosinate } \\
1.0-1.5\end{array}$ & $\begin{array}{l}\left(\text { Rely }^{\circledR} 280\right) 2.34 \mathrm{SL} \\
48-82 \mathrm{fl} \mathrm{oz}\end{array}$ & 10 & Bearing / nonbearing & $\begin{array}{l}\text { Broadleaf and grass weeds } \\
\text { PHI } 14 \text { days } \\
\text { Does not control goosegrass. Efficacy is reduced when } \\
\text { temperatures are cool or when weeds are under drought } \\
\text { stress. Direct spray solution to the base of the bush to } \\
\text { minimize contact with leaf, flower, and fruit tissue. Do not } \\
\text { apply to green or noncallused stems unless protected by } \\
\text { nonporous wraps, grow tubes, or waxed containers. Do not } \\
\text { apply more than } 3 \mathrm{lb} \text { a.i./acre. }\end{array}$ \\
\hline $\begin{array}{l}\text { Glyphosate } \\
0.5-1.5\end{array}$ & (Various formulations) & 9 & Bearing / nonbearing & $\begin{array}{l}\text { Broadleaf and grass weeds } \\
\text { PHI } 14 \text { days } \\
\text { Direct spray solution to the base of the bush to minimize } \\
\text { contact with green stems, leaves, and fruits. }\end{array}$ \\
\hline Halosulfuron & $\begin{array}{l}\text { (Sandea) 75DF } \\
1 \text { to } 4 \text { yr bushes } \\
0.5-0.6 \text { oz } \\
>4 \text { yr bushes } \\
0.5 \text { to } 1 \mathrm{oz}\end{array}$ & 2 & Bearing / nonbearing & $\begin{array}{l}\text { Broadleaf and sedge weeds } \\
\text { PHI } 14 \text { days } \\
\text { Avoid contact with green tissues and leaves. Do not apply } \\
\text { to bushes less than } 1 \text { year old. Minimum of } 45 \text { days between } \\
\text { applications. Do not apply more than } 2 \text { oz/acre per } 12 \text {-month } \\
\text { period. Cultivar tolerance is variable. 'Emerald' and 'Jewel' are } \\
\text { more tolerant. Some growers have reported 'Prima Donna', } \\
\text { 'Scintilla', and 'Springhigh' are less tolerant. }\end{array}$ \\
\hline $\begin{array}{l}\text { Mesotrione } \\
0.09-0.19\end{array}$ & $\begin{array}{l}\left(\text { Callisto }{ }^{\oplus}\right) 4 \mathrm{~L} \\
3-6 \text { fl oz }\end{array}$ & 27 & Bearing / nonbearing & $\begin{array}{l}\text { Annual broadleaf weeds } \\
\text { The University of Florida has conducted limited testing; thus, } \\
\text { any application should be made on a small acreage first to } \\
\text { determine cultivar tolerance. Apply before prebloom, or illegal } \\
\text { residues may occur. Can be applied as a split application } \\
\text { of } 3 \text { oz followed by } 3 \text { oz with no less than } 14 \text { days between } \\
\text { applications. Include a crop oil concentrate at } 1 \% \text { v/v. Limit } \\
\text { spray contact with green foliage and stems, or injury may } \\
\text { result. }\end{array}$ \\
\hline
\end{tabular}




\begin{tabular}{|c|c|c|c|c|}
\hline $\begin{array}{c}\text { Common Name } \\
\text { (Ib a.i./A) }\end{array}$ & $\begin{array}{l}\text { Trade Name } \\
\text { (product/A) }\end{array}$ & MOA & Crop Age & Comments \\
\hline $\begin{array}{l}\text { Paraquat } \\
0.56-1\end{array}$ & $\begin{array}{l}\left.\text { (Gramoxone Inteon }{ }^{\oplus}\right) \\
2 \mathrm{SL} \\
2-4 \mathrm{pt} \\
(\text { Firestorm } \\
1.3-2.7 \mathrm{pt}\end{array}$ & 22 & Bearing / nonbearing & $\begin{array}{l}\text { Broadleaf and grass weeds } \\
\text { Direct spray to the base of the stem. Use a coarse spray and } \\
\text { hooded sprayer to minimize contact with foliage. New canes } \\
\text { or shoots can be injured. Include a nonionic surfactant at } \\
0.125 \%-0.25 \% \mathrm{v} / \mathrm{v} \text { or crop oil concentrate at } 1 \% \mathrm{v} / \mathrm{v} \text {. }\end{array}$ \\
\hline Pelargonic Acid & $\begin{array}{l}(\text { Scythe })^{\oplus} \\
3 \%-10 \% \text { v/v }\end{array}$ & 27 & Bearing / nonbearing & $\begin{array}{l}\text { Broadleaf and grass weeds } \\
\text { Contact herbicide that should be applied with a shielded } \\
\text { sprayer and direct spray to the base of the bush to minimize } \\
\text { contact with green tissue. }\end{array}$ \\
\hline $\begin{array}{l}\text { Rimsulfuron } \\
0.063\end{array}$ & $\begin{array}{l}\left(\text { Matrix }^{\oplus}\right) \text { SG } \\
4 \mathrm{oz}\end{array}$ & 2 & Bearing / nonbearing & $\begin{array}{l}\text { Broadleaf weeds and nutsedge } \\
\text { PHI } 21 \text { days } \\
\text { Apply after the bushes have gone through one growing } \\
\text { season. Application after bud break may cause temporary } \\
\text { chlorosis and/or stunting of leaves. Do not apply more than } \\
4 \text { oz/acre per year. New label and should be trialed on a small } \\
\text { area before applying to the entire field. }\end{array}$ \\
\hline $\begin{array}{l}\text { Sethoxydim } \\
0.3-0.5\end{array}$ & $\begin{array}{l}\left(\text { Poast }^{\oplus}\right) 1.5 \mathrm{EC} \\
1.5-2.5 \mathrm{pt}\end{array}$ & 1 & Bearing / nonbearing & $\begin{array}{l}\text { Annual and perennial grass weeds } \\
\text { PHI } 30 \text { days } \\
\text { Consult label for exact rate to control specific grass species. } \\
\text { Multiple applications may be necessary to control perennial } \\
\text { grasses, such as bermudagrass. Include a crop oil concentrate } \\
\text { at } 1 \mathrm{qt} / \text { acre. }\end{array}$ \\
\hline
\end{tabular}




\begin{tabular}{|c|c|c|c|c|c|c|c|c|c|c|c|c|c|c|c|c|c|}
\hline & $\begin{array}{l}\text { Chick- } \\
\text { weed }\end{array}$ & $\begin{array}{l}\text { Galin- } \\
\text { soga }\end{array}$ & $\begin{array}{c}\text { Gera- } \\
\text { nium, } \\
\text { Carolina }\end{array}$ & $\begin{array}{l}\text { Com- } \\
\text { mon }\end{array}$ & $\begin{array}{l}\text { Hen- } \\
\text { bit }\end{array}$ & $\begin{array}{l}\text { Lambs- } \\
\text { quarter }\end{array}$ & $\begin{array}{l}\text { Morning- } \\
\text { glory, } \\
\text { annual }\end{array}$ & $\begin{array}{l}\text { Night- } \\
\text { shades }\end{array}$ & $\begin{array}{l}\text { Pig- } \\
\text { weed }\end{array}$ & $\begin{array}{l}\text { Radish, } \\
\text { wild }\end{array}$ & $\begin{array}{l}\text { Rag- } \\
\text { weed }\end{array}$ & $\begin{array}{l}\text { Prickly } \\
\text { sida }\end{array}$ & $\begin{array}{l}\text { Smart- } \\
\text { weed }\end{array}$ & $\begin{array}{c}\text { Spot- } \\
\text { ted } \\
\text { spurge }\end{array}$ & $\begin{array}{l}\text { Dande- } \\
\text { lion }\end{array}$ & $\begin{array}{l}\text { Smi- } \\
\text { lax }\end{array}$ & $\begin{array}{l}\text { Virginia } \\
\text { creeper }\end{array}$ \\
\hline \multicolumn{18}{|l|}{ Preemergence } \\
\hline $\begin{array}{l}\text { Dichlobenil } \\
\left.\text { (Casoron }^{\oplus}\right)\end{array}$ & G & $\mathrm{F}$ & G & G & G & G & $\mathrm{F}$ & $\mathrm{F}$ & G & G & G & - & G & G & G & $\mathrm{N}$ & $\mathrm{N}$ \\
\hline Diuron (Karmex ${ }^{\circledR}$ ) & G & - & - & - & $\mathrm{F}$ & G & G & - & $E$ & $\mathrm{~F}$ & $\mathrm{E}$ & $\mathrm{F}$ & $\mathrm{F}$ & - & $\mathrm{N}$ & $\mathrm{N}$ & $\mathrm{N}$ \\
\hline $\begin{array}{l}\text { Flumioxazin } \\
\left(\text { Chateau }^{\circledast}\right)\end{array}$ & G & G & G & - & $\mathrm{E}$ & $\mathrm{E}$ & $\mathrm{E}$ & $\mathrm{E}$ & $\mathrm{E}$ & G & $\mathrm{E}$ & G & G & $\mathrm{E}$ & G & $\mathrm{N}$ & $\mathrm{N}$ \\
\hline $\begin{array}{l}\text { Hexazinone } \\
\left(\text { Velpar }^{\oplus}\right)\end{array}$ & G & - & - & $\mathrm{E}$ & $\mathrm{F}$ & $\mathrm{E}$ & - & - & G & G & $\mathrm{E}$ & - & G & - & $E$ & - & - \\
\hline $\begin{array}{l}\text { Isoxaben } \\
\left(\text { Gallery }{ }^{\circledast}\right)\end{array}$ & G & G & G & G & G & G & $\mathrm{F}$ & G & G & G & G & G & G & G & G & $\mathrm{N}$ & $\mathrm{N}$ \\
\hline $\begin{array}{l}\text { Mesotrione } \\
\text { (Callisto }^{\oplus} \text { ) }\end{array}$ & - & - & - & - & - & G & $\mathrm{F}$ & G & G & - & $\mathrm{F}$ & $\mathrm{N}$ & G & - & $\mathrm{N}$ & $\mathrm{N}$ & $\mathrm{N}$ \\
\hline $\begin{array}{l}\text { Napropamide } \\
\left(\text { Devrinol }^{\circledR}\right)\end{array}$ & G & $\mathrm{F}$ & G & G & G & G & $\mathrm{P}$ & $\mathrm{P}$ & G & G & G & - & G & G & $\mathrm{P}$ & $\mathrm{N}$ & $\mathrm{N}$ \\
\hline $\begin{array}{l}\text { Norflurazon } \\
\left(\text { Solicam }^{\circledR}\right)\end{array}$ & $\mathrm{E}$ & $\mathrm{G}$ & - & $\mathrm{F}$ & G & $\mathrm{F}$ & $\mathrm{F}$ & G & $\mathrm{P}$ & G & $\mathrm{G}$ & $\mathrm{E}$ & G & $\mathrm{F}$ & G & $\mathrm{N}$ & $\mathrm{N}$ \\
\hline Oryzalin & G & $\mathrm{N}$ & - & $\mathrm{F}$ & $\mathrm{F}$ & $E$ & $\mathrm{~F}$ & $\mathrm{P}$ & $\mathrm{E}$ & $\mathrm{P}$ & $\mathrm{P}$ & $\mathrm{P}$ & $\mathrm{P}$ & $\mathrm{F}$ & $P$ & $\mathrm{~N}$ & $\mathrm{~N}$ \\
\hline $\begin{array}{l}\text { Pronamide } \\
\text { (Kerb }^{\oplus} \text { ) }\end{array}$ & G & $P$ & - & - & G & $E$ & G & G & G & $\mathrm{F}$ & - & - & $\mathrm{F}$ & - & $P$ & $\mathrm{~N}$ & $\mathrm{~N}$ \\
\hline $\begin{array}{l}\text { Simazine } \\
\text { (Princep }^{\oplus} \text { ) }\end{array}$ & G & G & $\mathrm{F}$ & $\mathrm{F}$ & G & $\mathrm{E}$ & $\mathrm{F}$ & G & G & $E$ & G & $\mathrm{F}$ & G & $P$ & $\mathrm{P}$ & $\mathrm{N}$ & $\mathrm{N}$ \\
\hline Terbacil $\left(\right.$ Sinbar $\left.^{\circledast}\right)$ & $E$ & - & G & $\mathrm{F}$ & $E$ & $E$ & - & G & - & $E$ & G & - & G & - & $\mathrm{F}$ & $\mathrm{N}$ & $\mathrm{N}$ \\
\hline \multicolumn{18}{|l|}{ Postemergence } \\
\hline $\begin{array}{l}\text { Carfentrazone } \\
\left(\text { Aim }^{\circledast}\right)\end{array}$ & $E$ & - & - & G & $\mathrm{E}$ & $\mathrm{E}$ & $\mathrm{E}$ & $E$ & $E$ & - & G & - & - & - & $\mathrm{N}$ & $\mathrm{N}$ & $\mathrm{N}$ \\
\hline $\begin{array}{l}\text { Clethodim } \\
\text { (Select }^{\oplus} \text { ) }\end{array}$ & $\mathrm{N}$ & $\mathrm{N}$ & $\mathrm{N}$ & $\mathrm{N}$ & $\mathrm{N}$ & $\mathrm{N}$ & $\mathrm{N}$ & $\mathrm{N}$ & $\mathrm{N}$ & $\mathrm{N}$ & $\mathrm{N}$ & $\mathrm{N}$ & $\mathrm{N}$ & $\mathrm{N}$ & $\mathrm{N}$ & $\mathrm{N}$ & $\mathrm{N}$ \\
\hline $\begin{array}{l}\text { Fluazifop } \\
\text { (Fusilade }^{\circledR} \text { ) }\end{array}$ & $\mathrm{N}$ & $\mathrm{N}$ & $\mathrm{N}$ & $\mathrm{N}$ & $\mathrm{N}$ & $\mathrm{N}$ & $\mathrm{N}$ & $\mathrm{N}$ & $\mathrm{N}$ & $\mathrm{N}$ & $\mathrm{N}$ & $\mathrm{N}$ & $\mathrm{N}$ & $\mathrm{N}$ & $\mathrm{N}$ & $\mathrm{N}$ & $\mathrm{N}$ \\
\hline $\begin{array}{l}\text { Glufosinate } \\
\left(\text { Rely }^{\circledast}\right)\end{array}$ & G & $\mathrm{F}$ & $\mathrm{F}$ & $\mathrm{F}$ & $\mathrm{F}$ & G & $\mathrm{E}$ & G & G & G & G & $\mathrm{F}$ & G & G & G & $P$ & $\mathrm{P}$ \\
\hline $\begin{array}{l}\text { Glyphosate } \\
\text { (Roundup) }\end{array}$ & $\mathrm{E}$ & G & G & $\mathrm{E}$ & $\mathrm{F}$ & $\mathrm{E}$ & G & $\mathrm{E}$ & $E$ & G & $\mathrm{E}$ & G & $\mathrm{F}$ & G & $\mathrm{F}$ & G & G \\
\hline Paraquat & G & G & $\mathrm{F}$ & $\mathrm{F}$ & $\mathrm{F}$ & G & G & G & G & $\mathrm{F}$ & G & G & G & G & $\mathrm{P}$ & $\mathrm{P}$ & $\mathrm{P}$ \\
\hline $\mathrm{Se}$ & $\mathrm{N}$ & $\mathrm{N}$ & $\mathrm{N}$ & $\mathrm{N}$ & $\mathrm{N}$ & $\mathrm{N}$ & $\mathrm{N}$ & $\mathrm{N}$ & $\mathrm{N}$ & $\mathrm{N}$ & $\mathrm{N}$ & $\mathrm{N}$ & $\mathrm{N}$ & $\mathrm{N}$ & $\mathrm{N}$ & $\mathrm{N}$ & $\mathrm{N}$ \\
\hline
\end{tabular}

$\mathrm{E}=$ Excellent, $\mathrm{G}=$ Good, $\mathrm{F}=$ Fair, $\mathrm{P}=$ Poor, $\mathrm{N}=$ No activity 
Table 10. Efficacy of preemergence and postemergence herbicides for annual and perennial grass and sedge weed control.

\begin{tabular}{|c|c|c|c|c|c|c|c|c|}
\hline & \multicolumn{4}{|c|}{ Annual grass } & \multirow{2}{*}{$\begin{array}{l}\text { Perennial } \\
\text { grass } \\
\text { Ryegrass, } \\
\text { annual }\end{array}$} & \multicolumn{2}{|c|}{ Sedge } & \multirow[b]{2}{*}{$\begin{array}{c}\text { Nutsedge } \\
\text { yellow }\end{array}$} \\
\hline & Crabgrass & Foxtail & Goosegrass & Panicum, fall & & Bermudagrass & $\begin{array}{c}\text { Nutsedge, } \\
\text { purple }\end{array}$ & \\
\hline \multicolumn{9}{|l|}{ Preemergence } \\
\hline $\begin{array}{l}\text { Dichlobenil, } \\
\left.\text { (Casoron }^{\circledR}\right)\end{array}$ & G & G & G & G & G & $\mathrm{N}$ & $\mathrm{N}$ & $\mathrm{N}$ \\
\hline $\begin{array}{l}\text { Diuron, } \\
\left(\text { Karmex }^{\circledast}\right)\end{array}$ & G & G & G & G & $\mathrm{F}$ & $\mathrm{N}$ & $\mathrm{N}$ & $\mathrm{N}$ \\
\hline $\begin{array}{l}\text { Flumioxazin, } \\
\left(\text { Chateau }^{\circledast}\right)\end{array}$ & $\mathrm{G}$ & G & $\mathrm{G}$ & $\mathrm{G}$ & G & $\mathrm{N}$ & $\mathrm{N}$ & $\mathrm{N}$ \\
\hline $\begin{array}{l}\text { Hexazinone, } \\
\left(\text { Velpar }^{\circledast}\right)\end{array}$ & $\mathrm{E}$ & $\mathrm{E}$ & G & G & $\mathrm{E}$ & $\mathrm{N}$ & $\mathrm{N}$ & $\mathrm{N}$ \\
\hline $\begin{array}{l}\text { Isoxaben, } \\
\left.\text { (Gallery }^{\circledR}\right)\end{array}$ & $\mathrm{P}$ & $\mathrm{P}$ & $\mathrm{P}$ & $\mathrm{P}$ & $\mathrm{P}$ & $\mathrm{N}$ & $\mathrm{N}$ & $\mathrm{N}$ \\
\hline $\begin{array}{l}\text { Mesotrione, } \\
\left(\text { Callisto }^{\circledR}\right)\end{array}$ & $\mathrm{F}$ & $\mathrm{P}$ & $\mathrm{P}$ & $\mathrm{P}$ & $P$ & $\mathrm{~N}$ & $\mathrm{~N}$ & $\mathrm{~N}$ \\
\hline $\begin{array}{l}\text { Napropamide, } \\
\text { (Devrinol }^{\circledast} \text { ) }\end{array}$ & G & G & G & G & G & $\mathrm{N}$ & $\mathrm{N}$ & $\mathrm{N}$ \\
\hline $\begin{array}{l}\text { Norflurazon, } \\
\text { (Solicam }^{\circledR} \text { ) }\end{array}$ & $\mathrm{E}$ & $\mathrm{E}$ & $\mathrm{E}$ & $\mathrm{E}$ & $\mathrm{E}$ & $\mathrm{P}$ & $\mathrm{P}$ & $\mathrm{P}$ \\
\hline $\begin{array}{l}\text { Oryzalin, } \\
\text { (Surflan }^{\circledR} \text { ) }\end{array}$ & $\mathrm{E}$ & $\mathrm{E}$ & $\mathrm{E}$ & G & G & $\mathrm{N}$ & $\mathrm{N}$ & $\mathrm{N}$ \\
\hline $\begin{array}{l}\text { Pronamide, } \\
\left(\text { Kerb }^{\circledR}\right)\end{array}$ & G & G & G & G & G & $\mathrm{P}$ & $\mathrm{P}$ & $\mathrm{P}$ \\
\hline $\begin{array}{l}\text { Simazine, } \\
\text { (Princep }^{\circledR} \text { ) }\end{array}$ & $\mathrm{F}$ & G & G & $\mathrm{F}$ & G & $\mathrm{N}$ & $\mathrm{N}$ & $\mathrm{N}$ \\
\hline $\begin{array}{l}\text { Terbacil, } \\
\left(\text { Sinbar }^{\circledast}\right)\end{array}$ & $\mathrm{E}$ & G & - & G & $\mathrm{E}$ & - & $\mathrm{F}$ & $\mathrm{F}$ \\
\hline \multicolumn{9}{|l|}{ Postemergence } \\
\hline $\begin{array}{l}\text { Carfentrazone, } \\
\left(\text { Aim }^{\oplus}\right)\end{array}$ & $\mathrm{P}$ & $\mathrm{P}$ & $\mathrm{P}$ & $\mathrm{P}$ & $\mathrm{P}$ & $\mathrm{N}$ & $\mathrm{N}$ & $\mathrm{N}$ \\
\hline $\begin{array}{l}\text { Clethodim, } \\
\text { (Select }^{\oplus} \text { ) }\end{array}$ & $\mathrm{E}$ & $\mathrm{E}$ & $E$ & $\mathrm{E}$ & $\mathrm{E}$ & $\mathrm{E}$ & $\mathrm{N}$ & $\mathrm{N}$ \\
\hline $\begin{array}{l}\text { Fluazifop, } \\
\text { (Fusilade }^{\circledR} \text { ) }\end{array}$ & G & G & G & G & G & $\mathrm{E}$ & $\mathrm{N}$ & $\mathrm{N}$ \\
\hline $\begin{array}{l}\text { Glufosinate, } \\
\text { (Rely }^{\circledR} \text { ) }\end{array}$ & $\mathrm{F}$ & G & G & G & G & $\mathrm{F}$ & $\mathrm{F}$ & $\mathrm{F}$ \\
\hline $\begin{array}{l}\text { Glyphosate, } \\
\text { (Roundup) }\end{array}$ & $\mathrm{E}$ & $E$ & $E$ & $\mathrm{E}$ & $E$ & $\mathrm{~F}$ & $\mathrm{~F}$ & $\mathrm{~F}$ \\
\hline $\begin{array}{l}\text { Paraquat, } \\
\text { (Gramoxone }^{\circledast} \text { ) }\end{array}$ & G & G & G & G & G & $\mathrm{P}$ & $\mathrm{P}$ & $\mathrm{P}$ \\
\hline $\begin{array}{l}\text { Sethoxydim, } \\
\left(\text { Poast }^{\circledR}\right)\end{array}$ & $\mathrm{E}$ & $\mathrm{E}$ & $\mathrm{E}$ & $\mathrm{E}$ & $\mathrm{E}$ & $\mathrm{E}$ & $\mathrm{N}$ & $\mathrm{N}$ \\
\hline \multicolumn{9}{|c|}{$\mathrm{E}=$ Excellent, $\mathrm{G}=$ Good, $\mathrm{F}=$ Fair, $\mathrm{P}=$ Poor, $\mathrm{N}=$ No activity } \\
\hline
\end{tabular}




\section{Plant Growth Regulators}

Table 11. Plant growth regulator use in Florida blueberry production.

\begin{tabular}{|c|c|c|c|c|c|c|}
\hline Problem & $\begin{array}{l}\text { Management } \\
\text { options }\end{array}$ & $\begin{array}{c}\text { Amount of } \\
\text { formulation per } \\
\text { acre }\end{array}$ & $\begin{array}{l}\text { Effectiveness } \\
\text { or importance }\end{array}$ & $\begin{array}{c}\text { Restricted } \\
\text { entry interval } \\
\text { (REI) }\end{array}$ & $\begin{array}{c}\text { Postharvest } \\
\text { interval } \\
\text { (PHI) }\end{array}$ & Comments \\
\hline $\begin{array}{l}\text { Certain southern } \\
\text { highbush and } \\
\text { rabbiteye cultivars } \\
\text { exhibit slow or } \\
\text { delayed leaf } \\
\text { development } \\
\text { as they emerge } \\
\text { from dormancy. } \\
\text { Delayed leafing } \\
\text { can result in } \\
\text { delayed fruit } \\
\text { ripening and cause } \\
\text { stress to plants } \\
\text { that set a heavy } \\
\text { crop but have } \\
\text { poor or delayed } \\
\text { leaf canopy } \\
\text { development. }\end{array}$ & $\begin{array}{l}\text { Dormex }{ }^{\mathrm{TM}} \\
\text { or Budpro }{ }^{\circledR}, \\
\text { or }(50 \% \\
\text { hydrogen } \\
\text { cyanamide) }\end{array}$ & $\begin{array}{l}\text { Typically } 1.5 \% \\
(\mathrm{v} / \mathrm{v}) \text { a Dormex } \\
\text { or Budpro } \\
\text { plus a nonionic } \\
\text { surfactant } \\
\text { not to exceed } \\
0.5 \%(\mathrm{v} / \mathrm{v}) \\
\text { on hydrogen } \\
\text { cyanamide- } \\
\text { tolerant cultivars } \\
\text { in north and } \\
\text { north-central } \\
\text { Florida. This } \\
\text { rate may cause } \\
\text { phytotoxicity in } \\
\text { low-chill areas } \\
\text { of central and } \\
\text { south-central } \\
\text { Florida. }\end{array}$ & $\begin{array}{l}++++ \\
\text { Certain cultivars }\end{array}$ & 72 hours & NA & $\begin{array}{l}\text { Hydrogen cyanamide should not } \\
\text { be used in combination with the } \\
\text { evergreen production system } \\
\text { where foliage is held throughout } \\
\text { the winter and plants are not fully } \\
\text { dormant. Hydrogen cyanamide } \\
\text { is highly toxic to humans and } \\
\text { is a restricted-use material with } \\
\text { very specific restrictions on } \\
\text { its handling and application, } \\
\text { including use of an enclosed } \\
\text { tractor cab. Follow all label } \\
\text { directions. Hydrogen cyanamide } \\
\text { will damage flower buds if applied } \\
\text { incorrectly. Applications should } \\
\text { be made } 30 \text { or more days prior } \\
\text { to natural flower and vegetative } \\
\text { bud break. Application is based on } \\
\text { stage of flower bud development; } \\
\text { thus, the time of application will } \\
\text { vary, but it is typically applied in } \\
\text { north-central Florida between } \\
\text { mid-December and early January. } \\
\text { Cultivars vary in their response } \\
\text { and sensitivity to injury. Use as a } \\
\text { small-scale test on cultivars with } \\
\text { unknown response to hydrogen } \\
\text { cyanamide. Do not apply within } \\
14 \text { days of oil application or within } \\
30 \text { days of copper fungicide } \\
\text { applications. }\end{array}$ \\
\hline
\end{tabular}

a Product label rates vary. Refer to individual labels.

Hydrogen cyanamide-additional information: Hydrogen cyanamide is highly corrosive to equipment and requires thorough cleaning after application. Avoid drift to nontarget areas. Hydrogen cyanamide may be toxic to green plant tissue. It is also toxic to pets, wildlife, and livestock. Thorough spray coverage is needed for a consistent, uniform response. A minimum of 50 gal per acre of spray mix is usually needed on mature southern highbush plantings. Hydrogen cyanamide advances leaf and flower bud development and may increase susceptibility to freezes. Flower buds sprayed at stage 3 or beyond (Figure 3) may be killed or injured by hydrogen cyanamide, especially at concentrations of $1.5 \%(\mathrm{v} / \mathrm{v})$ or greater of formulated product. Applications of $1.5 \%(\mathrm{v} / \mathrm{v})$ of formulated product to dormant plants of suitable cultivars that have received significant chilling and not progressed beyond stage 2 (Figure 2) of flower bud development are usually effective. Rates of formulated product of $2.5 \%(\mathrm{v} / \mathrm{v})$ or greater have resulted in significant flower bud injury in Florida. However, lower rates may also result in flower bud injury depending on cultivar, plant dormancy level, and stage of bud development. Hydrogen cyanamide should only be applied to dormant plants that have received some natural chilling. Typically, hydrogen cyanamide is applied in mid to late December or early January in north and north-central Florida, or sometimes earlier in central Florida, depending on weather and the natural progression of chilling. Refer to labels for more information on rate and timing of sprays. Cultivars that naturally leaf well may not benefit from hydrogen cyanamide applications. Certain cultivars have shown greater-than-average sensitivity to hydrogen cyanamide in Florida. These include 'Sharpblue', 'Windsor', 'Primadonna,',Jewel', and 'Colossus'. Individual cultivars vary in their response to hydrogen cyanamide and should be tested prior to large-scale use. Response to hydrogen cyanamide has been more erratic, and in some cases more flower bud injury has been observed in central and south-central Florida compared to north Florida, especially following mild winters. This may be because plants are not fully dormant at time of application and less natural chilling occurred in the more southern locations prior to application. Flower bud morphology may affect sensitivity to injury from hydrogen cyanamide. Cultivars that have loose bud scales (puffy appearance), such as 'Sharpblue', may be more sensitive to hydrogen cyanamide. 


\begin{tabular}{|c|c|c|c|c|c|c|}
\hline Problem & $\begin{array}{r}\text { Iranageme } \\
\text { options }\end{array}$ & & & $\begin{array}{c}\text { Restricted } \\
\text { entry interval } \\
\text { (REI) }\end{array}$ & & Comments \\
\hline $\begin{array}{l}\text { Poor fruit set } \\
\text { of rabbiteye } \\
\text { blueberries }\end{array}$ & $\begin{array}{l}\text { Gibberellic } \\
\text { acid (ProGibb } \\
\text { 4\% liquid } \\
\text { conc.), } \\
\text { GibGro } 4 \text { LS, } \\
\text { or Gibbex 4\% }\end{array}$ & $\begin{array}{l}24-32 \text { oz (4\% } \\
\text { gibberellic acid) } \\
\text { or } 24-32 \mathrm{~g} \\
\text { gibberellic acid } \\
\text { applied twice. } \\
\text { Total of } 48-64 \\
\text { oz/acre in most } \\
\text { cases }\end{array}$ & ++ & 12 hours & 40 days & $\begin{array}{l}\text { For use on rabbiteye blueberries. } \\
\text { Do not apply to southern } \\
\text { highbush varieties in Florida } \\
\text { because it can cause overfruiting. } \\
\text { Make first application when at } \\
\text { least } 40 \%-50 \% \text { of the blooms are } \\
\text { open and about } 10 \% \text { of the flower } \\
\text { petals have fallen. The second } \\
\text { application should be about } \\
10-18 \text { days later. Use a minimum } \\
\text { of } 40 \text { gal of water per acre. If the } \\
\text { spray solution is alkaline (pH } 8 \\
\text { or greater), lower the pH with a } \\
\text { buffering agent. Apply during } \\
\text { slow drying conditions. }\end{array}$ \\
\hline \multicolumn{7}{|c|}{ 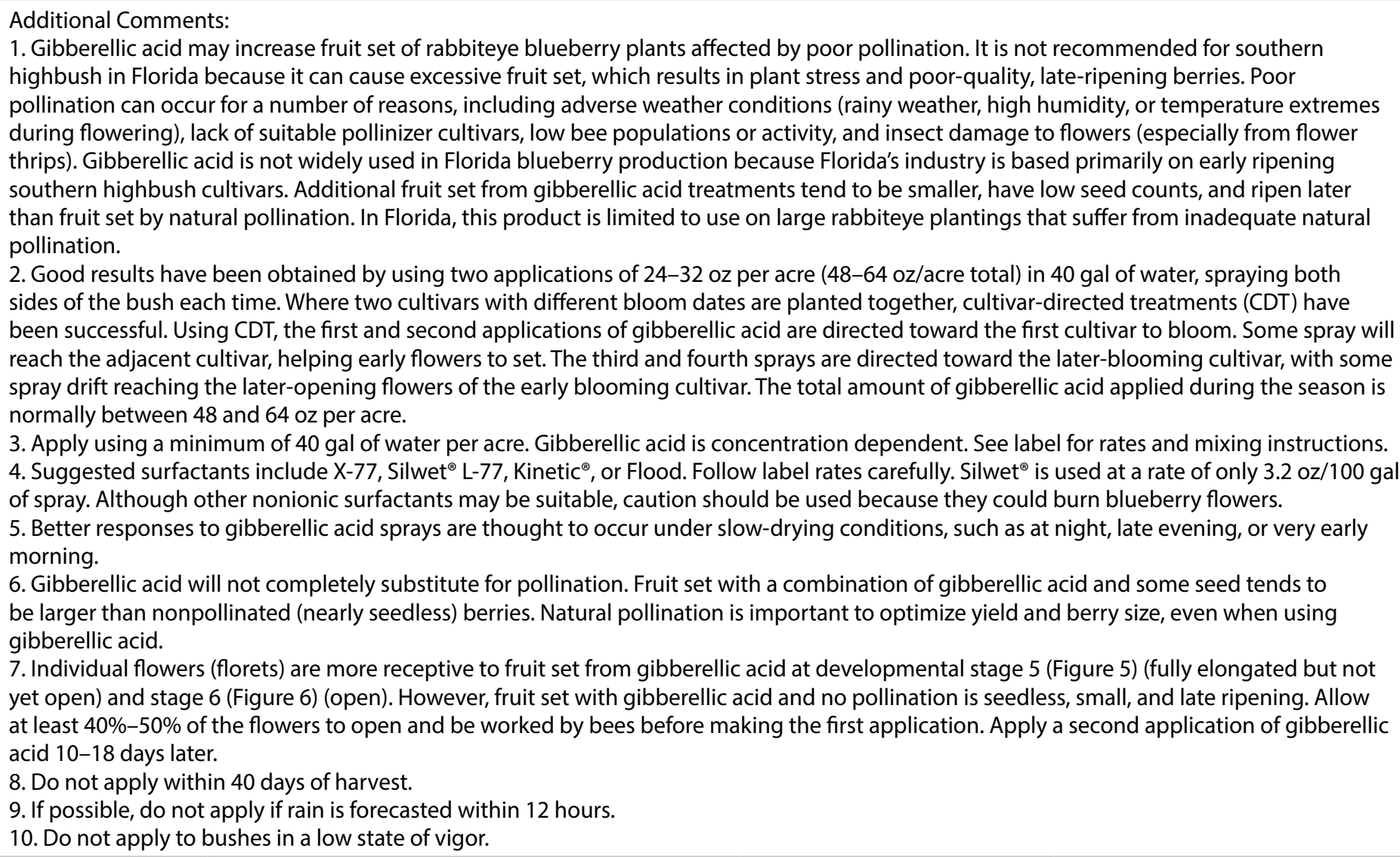 } \\
\hline
\end{tabular}

